\title{
Preservation of Modern and MIS 5.5 Erosional Landforms and Biological Structures as Sea Level Markers: A Matter of Luck?
}

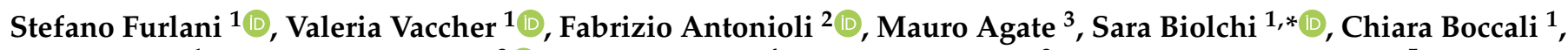 \\ Alice Busetti ${ }^{1}$, Francesco Caldareri ${ }^{3}{ }^{1}$, Fabio Canziani ${ }^{4}$, Renato Chemello ${ }^{3}$, Joanna Causon Deguara ${ }^{5}$, \\ Elisa Dal Bo ${ }^{6}$, Silas Dean ${ }^{7}\left(\mathbb{D}\right.$, Giacomo Deiana ${ }^{8}$, Eleonora De Sabata ${ }^{9}$, Yuri Donno ${ }^{10}$, Ritienne Gauci ${ }^{5}{ }^{(1)}$, \\ Thalassia Giaccone ${ }^{11}$, Valeria Lo Presti ${ }^{12}{ }^{1}$, Paolo Montagna ${ }^{13}$, Augusto Navone ${ }^{14}$, Paolo Emanuele Orrù ${ }^{5}$,

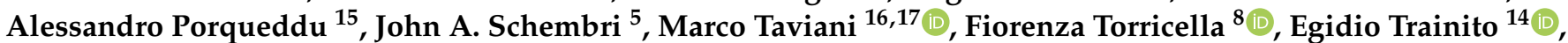 \\ Matteo Vacchi ${ }^{8}$ (D) and Elisa Venturini ${ }^{1,18}$ (i)
}

1 Department of Mathematics and Geosciences, University of Trieste, 34138 Trieste, Italy; sfurlani@units.it (S.F.); vvaccher@units.it (V.V.); chiara.boccali@gmail.com (C.B.); abusetti@units.it (A.B.); elisa.vnt@gmail.com (E.V.)

2 National Institute of Geophysics and Volcanology (INGV) , 90142 Palermo, Italy; fabrizioantonioli2@gmail.com

3 Department of Earth and Marine Sciences, University of Palermo, 90123 Palermo, Italy; mauro.agate@unipa.it (M.A.); francesco.caldareri@unipa.it (F.C.); renato.chemello@unipa.it (R.C.)

4 Studio Fabio Canziani, 33043 Cividale del Friuli, Italy; fabio.canziani2@gmail.com

5 Department of Geography, University of Malta, MSD 2080 Msida, Malta; jocdeg@gmail.com (J.C.D.); ritienne.gauci@um.edu.mt (R.G.); orrup@unica.it (P.E.O.); john.a.schembri@um.edu.mt (J.A.S.)

6 EGS International Ltd., Hampshire Bordon GU35 9QE, UK; elisadb93@libero.it

7 Department of Earth Science, University of Pisa, 56126 Pisa, Italy; silas.dean@dst.unipi.it

check for updates

Citation: Furlani, S.; Vaccher, V.; Antonioli, F.; Agate, M.; Biolchi, S.; Boccali, C.; Busetti, A.; Caldareri, F.; Canziani, F.; Chemello, R.; et al. Preservation of Modern and MIS 5.5 Erosional Landforms and Biological Structures as Sea Level Markers: A Matter of Luck? Water 2021, 13, 2127. https://doi.org/10.3390/w13152127

Academic Editor: Giorgio Anfuso

Received: 3 July 2021

Accepted: 27 July 2021

Published: 2 August 2021

Publisher's Note: MDPI stays neutral with regard to jurisdictional claims in published maps and institutional affiliations.

Copyright: (c) 2021 by the authors. Licensee MDPI, Basel, Switzerland. This article is an open access article distributed under the terms and conditions of the Creative Commons Attribution (CC BY) license (https:// creativecommons.org/licenses/by/ $4.0 /$ )
8 Department of Chemical and Geological Sciences, University of Cagliari, 09042 Cagliari, Italy; giacomo.deiana@unica.it (G.D.); fiorenza.torricella@phd.unipi.it (F.T.); matteo.vacchi@unipi.it (M.V.)

9 MedSharks, 00197 Rome, Italy; edesabata@gmail.com

10 National Park of the Maddalena Archipelago, 07024 La Maddalena, Italy; y.donno@lamaddalenapark.org

11 Independent Researcher, Via Morgioni 27C, 95027 San Gregorio di Catania, Italy; thalassia.giaccone@libero.it

12 Studio Tecnico, Via Montepellegrino 163, 90142 Palermo, Italy; valeria.lopresti@gmail.com

13 CNR-ISP, Institute of Polar Sciences, 40129 Bologna, Italy; paolo.montagna@bo.ismar.cnr.it

14 MPA Tavolara, 07026 Olbia, Italy; direzione@amptavolara.it (A.N.); et@egidiotrainito.it (E.T.)

15 Independent Researcher, Via Eleonora D'Arborea, 28, 07024 Sassari, Italy; aleporqueddu@gmail.com

16 CNR-ISMAR, Institute of Marine Sciences, 40129 Bologna, Italy; marco.taviani@bo.ismar.cnr.it

17 Stazione Zoologica "Anton Dorn", 80121 Napoli, Italy

18 National Institute of Oceanography and Applied Geophysics (OGS), 33100 Udine, Italy

* Correspondence: sbiolchi@gmail.com

Abstract: The Mediterranean Basin is characterized by a significant variability in tectonic behaviour, ranging from subsidence to uplifting. However, those coastal areas considered to be tectonically stable show coastal landforms at elevations consistent with eustatic and isostatic sea level change models. In particular, geomorphological indicators—such as tidal notches or shore platforms-are often used to define the tectonic stability of the Mediterranean coasts. We present the results of swim surveys in nine rocky coastal sectors in the central Mediterranean Sea using the Geoswim approach. The entire route was covered in 22 days for a total distance of $158.5 \mathrm{~km}$. All surveyed sites are considered to have been tectonically stable since the last interglacial (Marine Isotope Stage 5.5 [MIS 5.5]), because related sea level markers fit well with sea level rise models. The analysis of visual observations and punctual measurements highlighted that, with respect to the total length of surveyed coast, the occurrence of tidal notches, shore platforms, and other indicators accounts for $85 \%$ of the modern coastline, and only $1 \%$ of the MIS 5.5 equivalent. Therefore, only $1 \%$ of the surveyed coast showed the presence of fossil markers of paleo sea levels above the datum. This significant difference is mainly attributable to erosion processes that did not allow the preservation of the geomorphic evidence of past sea level stands. In the end, our research method showed that the feasibility of applying such markers to define long-term tectonic behaviour is much higher in areas where pre-modern indicators have not been erased, such as at sites with hard bedrock previously covered by post-MIS 5.5 continental deposits, e.g., Sardinia, the Egadi Islands, Ansedonia, Gaeta, and Circeo. In general, the chances of finding such preserved indicators are very low. 
Keywords: coastal geomorphology; MIS 5.5; landforms; biological indicators; sea level change; Mediterranean Sea; Geoswim

\section{Introduction}

Sea level rise and fall are due to planetary-scale processes, and constitute one of the major climate-driven effects on the coastal landscape. The main factors are global warming - which is driving the melting of ice and the thermal expansion of the oceansand the vertical tectonic movements of the coasts, which may increase or reverse the submersion processes of the coastal zones. Tectonic movements are particularly significant along the coasts of the Mediterranean Sea, due to the active tectonism in many parts of the basin [1] - the latter also shaped by geological and geomorphological processes driven by changes in sea level over millions of years [1]. About $60 \%$ of the Mediterranean Basin is bordered by rocky coasts [2], which are characterised by landforms related to paleo sea levels, such as tidal notches, marine terraces, vermetid reefs, etc. (e.g., [1,3-5]).

Fossil markers of former sea levels provide fundamental information related to changes in climate during glacial and interglacial periods, regional ice-sheet variations, rate and geographic source of meltwater influx, as well as on the rheological structure of the solid Earth - a key parameter for understanding mantle flow and the tectonic evolution of our planet (e.g., [6-8]).

The presence of fossil shorelines above or below the present mean sea level is not continuous, because their preservation is likely related to the complex interplay between erosion and deposition, which has been scantily investigated in a comprehensive way-notably along the rocky coasts.

The Mediterranean's sea level history has been studied by a number of authors (e.g., [1,9-15]). These studies provide important notions about the tectonic behaviour of the Mediterranean coastal zones from comparisons of measured data with eustatic and glacio-hydro-isostatic sea level rise models. Sea level indicators can be related to past sea levels thanks to their morphometric, biological, chemical, or sedimentological features. Common sea level indicators include tidal notches (e.g., [14,15]), marine terraces (e.g., [16]), vermetid reefs [17-19], beach rocks ([20,21]), submerged speleothems (e.g., [22] and references therein), etc. Archaeological artefacts also play an important role in defining past sea levels, as reviewed by [23]. On rocky coasts, geomorphological and biological indicators of paleo sea levels can be easily found thanks to favourable topographical setting and good preservation [2]. However, very short sections of rocky coasts were extensively surveyed in the field [24], mainly because of their difficult accessibility. In recent years, the Geoswim programme aimed at collecting visual observations and instrumental data along wide sections of rocky coasts and correlate these data with sea level change $[2,25,26]$ in 16 coastal areas [21]. This approach facilitates uninterrupted surveys of long sections of rocky coasts through the mapping, description, and measurement of sea level markers.

In this paper we present and discuss data on modern and relict erosional landforms - such as tidal notches and shore platforms-and bioconstructions surveyed in nine coastal sectors in the central Mediterranean area in the framework of the Geoswim programme [24]. The study was carried out on the islands of Marettimo, Favignana, and Levanzo (the Egadi Islands, Strait of Sicily), in Gaeta, Circeo, and Ansedonia (mid-northern Tyrrhenian Sea), Capo Caccia, on the islands of Razzoli, Budelli, Santa Maria, and Tavolara (Sardinia), and the island of Malta. In addition, we achieved a detailed data collection along $500 \mathrm{~m}$ of coast in the Arenella harbour (Palermo, Sicily), with measurements taken at every $20 \mathrm{~m}$ of coast.

Finally, we also report and measure the presence/absence of both modern and fossil shorelines along the rocky coastlines in areas that are considered tectonically stable (e.g., far from the major Mediterranean faults and characterized by negligible historical tectonic activity). Geomorphological and biological observations encompassing the suprati- 
dal, intertidal, and nearshore zones are made to discuss the possible factors that may favour the preservation of fossil markers of sea level change with respect to lithology and environmental setting.

\section{Geological and Geomorphological Setting of the Study Area}

The Mediterranean coastline extends for approximately $46,000 \mathrm{~km}$, with ca. $50 \%$ of it made up of rocky coasts [27] in the forms of plunging cliffs, sloping coasts, screes, shore platforms, and pocket beaches [28,29]. The Mediterranean has a long and complex geological history that began about 250 Mya ago, following the breakup of the continent of Pangaea and the formation of the Tethys Ocean-the forerunner of the Mediterranean [30]. The Mediterranean is usually divided into the Western and Eastern Mediterranean along an imaginary axis in correspondence to the Strait of Sicily and Tunisia [31], and many authors also identify an undefined "central Mediterranean area" (e.g., [5,32]). The central Mediterranean includes many large islands, of which Sicily is the largest, followed by Sardinia.

Inside this central Mediterranean area, we positioned the location of our surveys corresponding to two main sectors: the Tyrrhenian Sea, and the Strait of Sicily (Figure 1). These two distinct sectors were characterized by very different geological evolution during the late Neogene-Quaternary time interval, and currently are characterized by very different physiographic settings. The Tyrrhenian Sea-the location of most (seven) of the studied sites (Figure 1) -is a late Neogene deep basin characterized by a complex morphostructural setting. It opened during the middle Miocene [33] inside the suture zone between the European and African plates as a back-arc basin, related to the north-westward subduction of the Ionian Sea lithospheric slab beneath the Calabrian Arc [34,35].

The Tyrrhenian Sea displays an almost triangular shape, and is a landlocked basin bordered by the Apennine mountain belt and Calabrian Arc to the east, by the SicilianMaghrebian mountain belt to the south, and by the Corsica-Sardinia Block to the west (Figure 1). The main exchanges of water masses take place to the north with the Ligurian Sea and to the southwest with the Algerian-Provençal Basin through the Sardinian Channel.

Around the Tyrrhenian Sea, the continental shelf is usually less than $20 \mathrm{~km}$ wide, seaward-bounded by a shelf break positioned at an average water depth of about $128 \mathrm{~m}$ [36]. Except in front of major fluvial deltas, the shelf displays thin, locally absent, modern sedimentary coverage. Along the shelf edge, prograding accretionary wedges alternate [37], in a direction parallel to the margin and with structural-type shelf breaks. All around the Tyrrhenian margins, across the continental shelf it is possible to separate an inner and an outer segment, showing different morphological features: the inner segment could display a mostly regular seabed morphology as a consequence of accumulation of Holocene aggrading to prograding sediments or, alternatively, it could be characterized by a rough seabed morphology as a consequence of subaerial exposure that occurred during the latest Pleistocene global sea level lowstand; the outer segment is mostly devoid of a sedimentary cover and, eventually, characterized by a sharp erosional surface originating during the shoreface retreat related to the last sea level rise (the Holocene transgression).

Along the Sicilian coast, the continental shelf is less wide (usually less than $10 \mathrm{~km}$ ) as a consequence of a reduced sedimentary supply due to the absence of major rivers; the maximum width is found in the Castellammare Gulf (up to $12 \mathrm{~km}$; [38]) and in the Termini Imerese Gulf (up to $11 \mathrm{~km}$; [39]).

Along the Sardinian coast the continental shelf is no more than $14 \mathrm{~km}$ wide, because of a moderate sedimentary supply and a series of faults arranged north-south parallel to the margin.

The eastern Sardinian margin shows a morphostructural setting interpreted as a passive continental margin related to a Tortonian rifting episode, resulting in a tilted fault block setting from where both the Sardinian Basin and Cornaglia Terrace originated. The latter is bounded eastwards by a prominent northeast-southwest trending fault scarp-the 
Selli Line- that separates the Sardinian passive margin from the Vavilov bathyal plain with a relief of about $1000 \mathrm{~m}$ above the sea bottom.

Only in the eastern and southern margins did the lower segment of the continental slope record a rifting episode and intense crustal thinning with kilometre-scale fault scarps; however, the upper slope is associated with seismicity, active volcanism, and elevated uplift rates of mainland areas, represented by the Apennine and Maghrebian mountain belts, respectively.

Similarly, along the margins there is evidence of the effects generated by eustatic sea level changes and by major sedimentary transport processes that have accumulated Neogene-Quaternary deposits in the intraslope basins and in the bathyal plains.

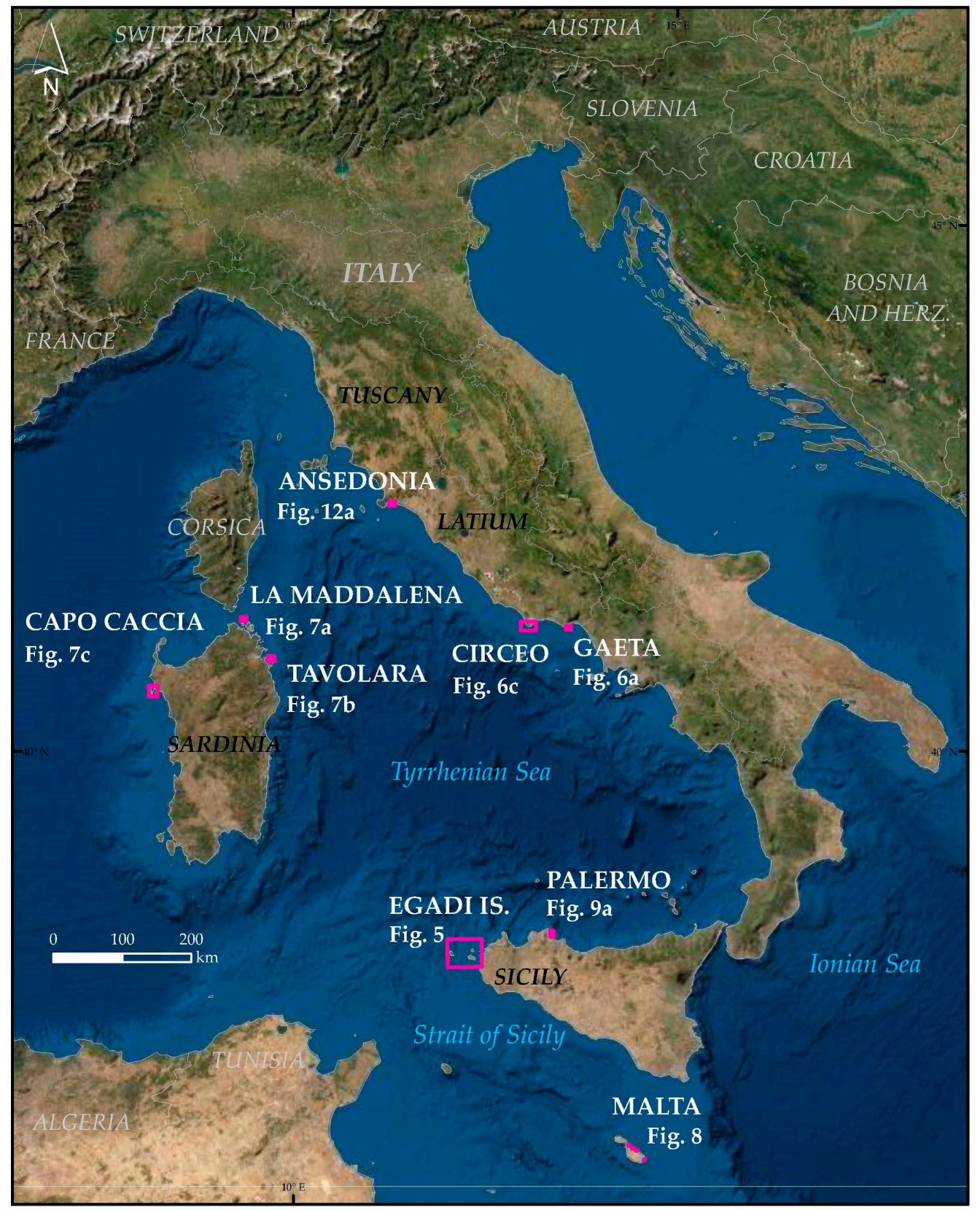

Figure 1. The study areas and the surveyed sites.

In the Strait of Sicily area, we focused our investigation (four sites) inside its eastern sector-the Hyblean-Maltese Plateau, which has acted as the foreland of the Sicilian fold-and-thrust belt since the Miocene [39]. The plateau is bounded by the outer front of 
the Sicilian-Maghrebian thrust belt to the north, the Malta Escarpment to the east, the Malta-Linosa graben to the south, and the Gela foredeep basin to the west (Figure 2). The Malta Escarpment plunges steeply to the deeper floors of the Ionian Sea (>2000 m); to the west, the boundary of the plateau is not well defined: indeed, in this sector, the sea floor slightly deepens toward the Gela Basin, which represents the present-day foredeep of the Sicilian-Maghrebian fold-and-thrust belt filled with Quaternary to recent (mostly) siliciclastic sediments.

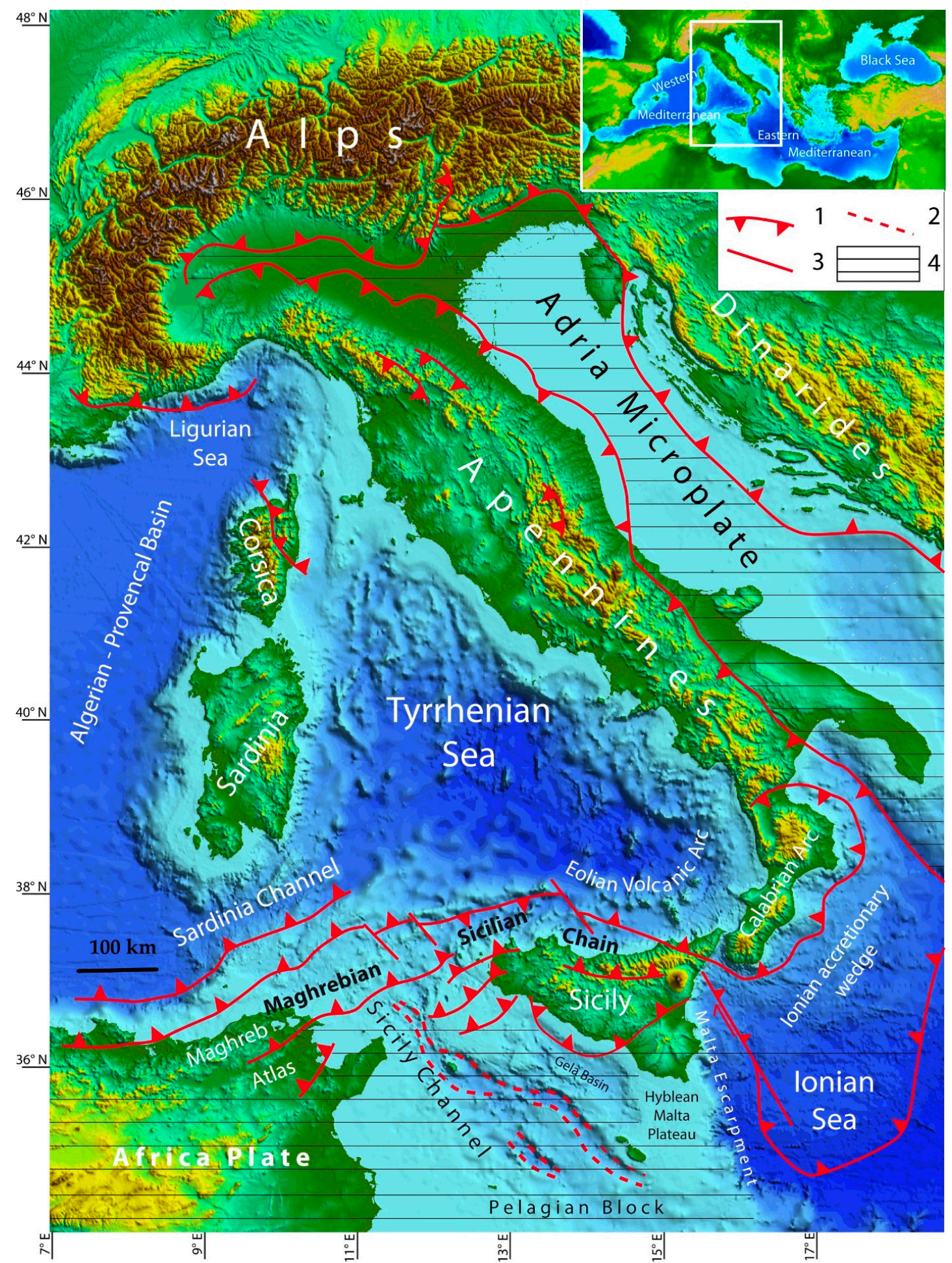

Figure 2. Simplified structural map of the central Mediterranean Sea, showing the main tectonic structures related to the Ionian subduction system. Colour relief is derived from data downloaded from GEBCO gridded bathymetry ([40]). 
Structural features are summarized in [41] (for the Italian Peninsula and Adriatic Sea sectors) and [42] (for the Sardinian Channel and Strait of Sicily sectors). The inset in the top right corner shows the location of the central Mediterranean region with respect to the Mediterranean Sea overall. Legend: (1) main thrust front; (2) main normal fault; (3) fault; (4) non-deformed continental crust belonging to the African Plate and Adria Microplate.

During the lowstand related to LGM (about 20-18 ka B.P.), the Hyblean-Maltese Plateau was almost completely exposed to subaerial processes, and an enhanced erosional surface developed extensively across the plateau, which truncated Pleistocene and older rocks. Presently, the submerged sector of the Hyblean-Maltese Plateau represents an extensive continental shelf area with a mostly smooth, regular seabed [43], and a shelf break at a depth between 140 and $160 \mathrm{~m}$, in the eastern and western sectors, respectively.

On the Maltese Islands, faults trend mostly northwest-southeast, as well as eastnortheast-west-southwest, bounding horst and graben structures that pond and trap sediments; most of the faulting occurred at approximately middle Pliocene time, but some faulting also occurred during Pleistocene time [43]. The fault system could be currently active [44] in the framework of a transtensional fault system accounting for dextral strike-slip focal mechanisms of recent earthquakes and active gas seepage/fluid ascent and venting. The islands are among the few onshore parts in the Strait of Sicily's rift zone, and provide evidence as to the channel's intricate northeast-southwest-oriented faulting system (Great Fault) of the early Miocene (23-16 ma) by displaying a fractured Maltese sedimentary landscape. The latter shows a series of ridges and flat-floored valleys on the hinterland and headlands and bays (and rias) along its coast [44,45]. Tectonic upwarping and associated rifting during the Pliocene developed both a second set of faults in a northwest-southeast direction on the southern coast of Malta (Maghlaq Fault), and most importantly, a north-east structural tilt to the archipelago between $5.3 \mathrm{ma}$ and 1.8 ma ago [46,47]. The northeastern tilting shaped the southern coast of Malta, with elevated vertical cliff faces in full stratigraphic sequence and, conversely, dipped most of the northeastern and eastern coast as low sloping profiles.

The coastal topographies, coupled with seismic activity generated by geodynamics, drive most erosional processes within the area. The resultant geomorphic features on rocky coasts include sea cliffs and shore platforms, plunging cliffs, etc., which are located at different altitudes with respect to the modern sea level [27]. The combination of raised and drowned shorelines defines the active nature of tectonics in the Mediterranean. The spatial variation in uplift can be highlighted, e.g., by geomorphological markers, such as tidal notches, marine terraces, or other tidal landforms, together with other well-defined markers, such as archaeological and sedimentological ones (e.g., [1,5]).

For the aforementioned reasons, rocky coastal landforms in the Mediterranean Sea are closely connected with its sea level history [5]. These coastal landforms can be found from a few metres up to more than $100 \mathrm{~m}$ ASL in elevation, due to the relevant tectonic uplift that patchily affects the basin's coastline [1]. Pleistocene high stands have mainly been responsible for the formation of stepped flights of terraces along the rocky sections of the Mediterranean Sea.

The typical Mediterranean climate comprises hot, dry summers and mild and rainy winters [48]. Water circulation and environmental evolution in the Mediterranean Sea are tightly controlled by the Strait of Gibraltar. Water circulation is driven by interactive factors, such as climate, topography and depth, which can lead to precipitation of evaporites. In the Mediterranean, evaporation greatly exceeds precipitation and river runoff, and this also affects the circulation of water within the basin [49]. Evaporation is especially high in the eastern Mediterranean, and causes the water level to decrease and salinity to increase [50]. This pressure gradient pushes relatively cool, low-salinity water from the Strait of Gibraltar across the basin. Here, it warms and becomes saltier as it moves eastwards, before sinking in the eastern Mediterranean and moving back westwards, to spill out as deep waters through the Strait of Gibraltar. Thus, following [48], there is an exchange of an eastward inflow through the strait as surface waters, and a westward outflow as deeper waters. 
The mean vertical variation of tides is ca. $0.4 \mathrm{~m}$, as a result of the narrow connection with the Atlantic Ocean [50]. Site-specific topographic features can reduce or amplify tide amplitudes [51].

\section{Erosional Landforms Related to the Sea Level}

The amount of deformation that has occurred is defined by identifiable features that have been displaced due to tectonic processes [52]. The authors recognize that the best tectonic markers meet three criteria: a known initial undeformed geometry, a known age, and a high preservation potential with respect to the timescale of the studied processes. Sea level geomorphological markers potentially fit all three criteria very well. In a coastal area, the tectonic behaviour is defined by a set of indicators of various kinds. Apart from the geomorphological indicators, additional markers-such as sedimentological, biological, and archaeological markers - can contribute to the evaluation of the tectonic rates. MIS 5.5 markers represent the most useful ones because they encompass a period of $125 \mathrm{ka}$, from the last interglacial period. In some cases, coastal markers represent the only local available data to establish the tectonic attitude of an area.

Marine processes have operated on rocky coasts at the modern sea level to model shore-zone landforms totally or partly related to the sea level, such as tidal notches, marine terraces, and sea caves. We chose these landforms because they are the ones most commonly used in sea level studies on rocky coasts, and they are also part of the data collected within the Geoswim programme [24].

Regarding the elevation of MIS 5.5 sea level markers, we have considered an area that is tectonically stable when the altitudes of sea level markers range from $0 \mathrm{~m}$ to $10 \mathrm{~m}$ ASL.

In our surveys, we identified, mapped, and measured the coastal landforms as shown in Figure 3. We added the terms "modern" and "fossil" to the aforementioned coastal landforms because the discussion regards their evolution within the sea level history of the studied areas. In the following sections, we describe these landforms and their relation to modern and fossil sea levels.

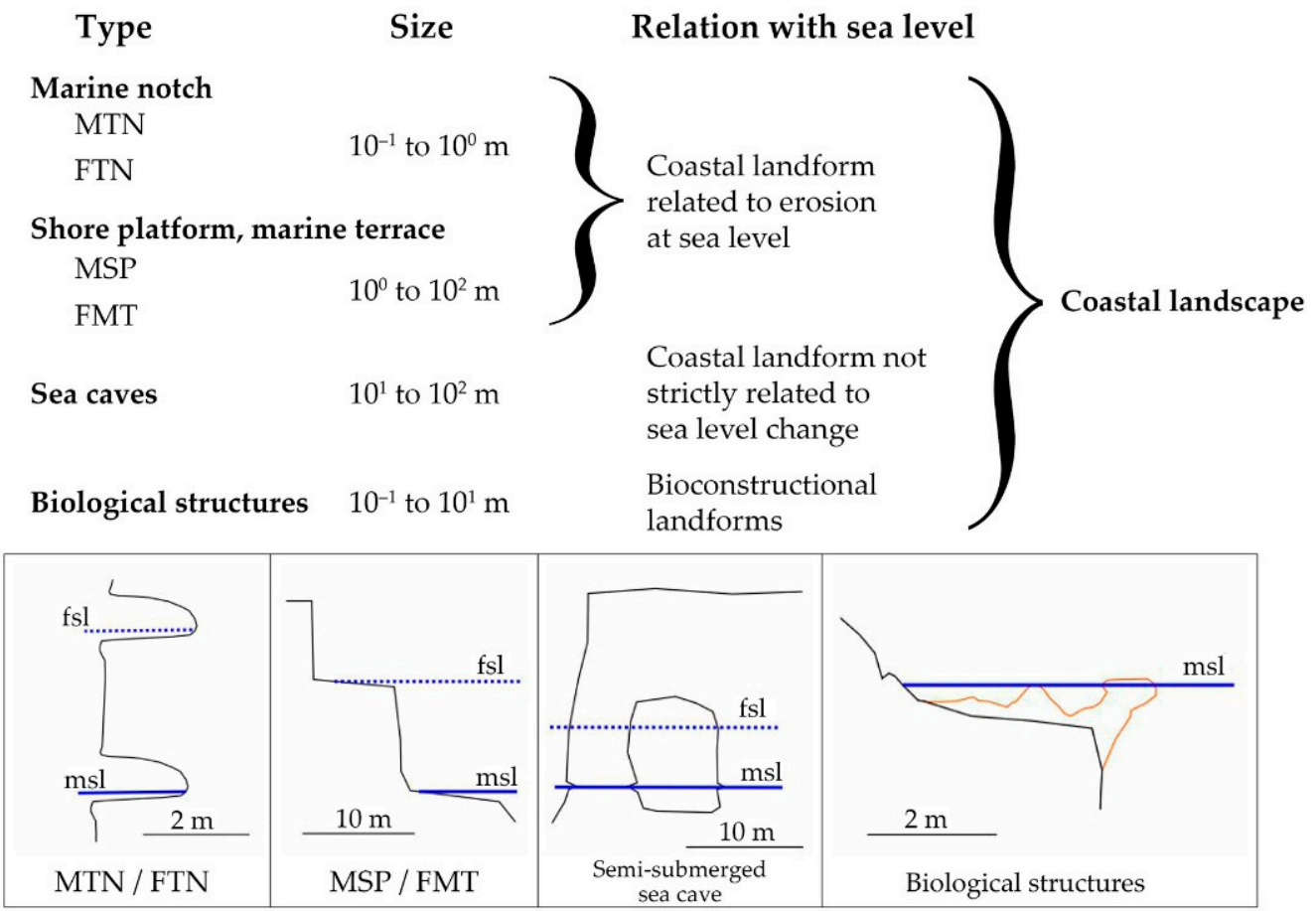

Figure 3. Coastal landforms studied in the Geoswim expeditions, with a graphical representation at the bottom of the figure. The solid line represents the current sea level, while the dotted line represents the fossil sea level. 


\subsection{Modern Tidal Notches (MTNs) and Fossil Tidal Notches (FTNs)}

A tidal notch is a laterally extending hollow at the base of a cliff, or at the sea level, with the width being greater than its depth $[53,54]$. The authors of [14] described the morphometric parameters of 73 sites with MTNs in the Mediterranean area. They ascribed the occurrence of MTNs to a range of marine processes - such as bioweathering, chemical dissolution, and wave processes-that have a regime that is often difficult to separate. The authors of [13] suggested that over the last $6.8 \mathrm{ka}$, MTNs have changed their shape following the relative sea level rise, causing sea cliff retreat. The authors of [55] described FTNs at 80 sites in the same area. They found that FTNs' shape is similar to that of MTNs, but FTNs are always a few centimetres wider than MTNs-probably due to the lack of a biological reef, and to the weathering/erosion processes that have occurred since their formation.

\subsection{Modern Shore Platforms (MSPS) and Fossil Marine Terraces (FMTs)}

Modern shore platforms (MSPs) are horizontal or gently sloping surfaces developed along shore by wave erosion and other weathering processes. The authors of $[53,56]$ identified two types of shore platforms: the first are gently sloping-also called ramps-while the second type are sub-horizontal platforms - either supra-, inter-, or subtidal—which terminate with a low-tide cliff. The former is mainly developed in macrotidal regions, while the latter in meso- and microtidal ones [56]. Although shore platforms and marine terraces are used almost interchangeably, the term marine terrace is often used to refer to fossil marine terraces (FMTs), in particular in sea level change studies.

\subsection{Sea Caves}

Although sea caves are not considered to be indicators of sea level variation, they may preserve sea level change markers, such as fossil tidal notches or speleothems ([57], this article).

Sea caves can be divided into two major types: sea caves, and flooded caves [58]. The first type includes caves formed by marine processes, while the second type includes caves developed under subaerial processes that occurred in dry conditions, which were then submerged by the Holocene marine transgression. Tidal effects, together with the mixing of seawater and fresh water, can also be fundamental in the shaping of extensive coastal karst systems $[59,60]$. Sea caves can be actively forming along modern coastlines, or they can be relict sea caves on former coastlines, e.g., at the elevation of MIS 5.5 sea level. The formation of sea caves is mainly controlled by geological weakness, such as bedding planes, joints, and faults along sea cliffs [53]. The authors of [61] identified a third group, called flank margin caves; these are dissolution landforms whose genesis is due to water mixing in sealed chambers. Coastal caves can develop in different salinity environments.

\subsection{Biogenic Structures}

Vermetid reefs are bioconstructions built by gregarious gastropods, occurring in the warmer sections of the Mediterranean Sea. They are found mainly on the coasts, with average surface temperatures not lower than $14{ }^{\circ} \mathrm{C}$ in winter and $24{ }^{\circ} \mathrm{C}$ in summer. The northern limit of distribution does not seem to exceed $38^{\circ} \mathrm{N}$. They are considered excellent biological markers of sea level change over the last two millennia because of their quite restricted bathymetric distribution and considerable extent [18]. The authors of [62] codified the main biogenic morphologies useful to define vermetid reefs, although a discussion about hydrodynamics or the role of substrates was not fully contemplated.

Vermetid reefs and minor bioconstructions live in the lower mediolittoral and in the upper infralittoral zones only on the rocky coasts, with less impressive structures in descending order from calcarenites, limestones, dolomites, and basalts through to flysch $[63,64]$. The presence of an abrasion platform and surface hydrodynamic activities, however, are the fundamental conditions for the construction of a real reef, while the inclination of the coast regulates the shape and size of these bioconstructions (the larger 
reefs are found between $15^{\circ}$ and $40^{\circ}$ with respect to the horizontal line assumed at the value $0[65])$.

Vermetid reefs and minor bioconstructions are the most widely distributed biogenic structures in the Egadi Islands-above all around Favignana and Levanzo-between the headland of Cefalù and the coast of Trapani, and in the Maltese Islands. Some thick incrustations and cornices are reported in the province of Syracuse, while there is a point relief on the southern side of the island of Lampedusa. Small formations are also present in Ustica, Capo di Milazzo [66], and Taormina. They can be found as crusts (a thin formation made by a single layer of Dendropoma spp. shells cemented by encrusting red algae), ledges or rims (usually less than $1 \mathrm{~m}$ wide and $20-30 \mathrm{~cm}$ thick), and true reefs, often wider than $4-5 \mathrm{~m}$ and thicker than 30-40 cm [61,66]. Israel has the widest platforms in the Mediterranean - up to 20 metres. Microatolls or mushroom-like pillars (according to [62]) were found around the Egadi Islands, in particular on the northern coast of Favignana.

\section{Material and Methods}

\subsection{Field Survey Approach}

The 11 sites were surveyed using the Geoswim approach described in [24]. The snorkel surveys were carried out using a specially built raft (Figure 4) to support the swimming activities and to host all the instruments, such as cameras, GPS, CTD sensors, and echosounders [24]. The raft was $1.15 \mathrm{~m}$ long, $0.57 \mathrm{~m}$ wide, and $0.13 \mathrm{~m}$ high, with a weight of $3 \mathrm{~kg}$. It was made about $0.98 \mathrm{~g} / \mathrm{cm}^{3}$ of from ethylene-vinyl acetate (EVA)-a light polymer with excellent resistance to UV-and it was certified to be unsinkable by the producers. The raft was modified by adding L-section aluminium bars fixed from bow to stern above and below the boat, in order to facilitate the housing of the instruments (Figure $4 a, b$ ). A set of cable holders firmly fixed the instruments on the raft in order to prevent detachment and loss of instruments. Moreover, a removable homemade plastic dome was fixed to the bow of the raft (Figure 4c) to collect videos and images at water level. The dome was $0.40 \mathrm{~m}$ in diameter, and could host two cameras to collect videos and images, or to document the surveying activities. An aluminium roll bar was set on the stern of the raft. In the bow there was also a scuba gear dive flag for the safety of surveyors. The raft was usually pushed by swimming during the surveying activities.

One or more cameras can be set in waterproof housings and allow for the collection of ongoing videos and time-lapse images of the coastline being surveyed, both above and below the waterline (Figure 4d). Different settings of cameras were adopted during the expeditions (Table 1) for the collection of videos or images as needed. The cameras were set laterally with respect to the raft in order to collect time-lapse images every second in the direction of navigation. The cameras set below the waterline included a TELESIN plastic dome 6 inches in diameter for superior optical performance in the seawater (Figure 4c). In the homemade dome fixed to the bow (Figure 4c), the cameras could collect videos above and below the waterline simultaneously thanks to the geometry of the lens itself; these were used to document the field surveys. The raft could also support waterproof LED lamps for the surveys within sea caves.

A portable H22PX digital sonar echosounder (HawkEye ${ }^{\circledR}$ Electonics, FL, USA), with a minimum depth of $0.6 \mathrm{~m}$ and maximum depth of $61 \mathrm{~m}$, was housed on the boat to collect any additional depth data at prominent sites. A radio and an additional GPS were also used during the surveys.

The survey followed pre-planned routes at roughly 1-5 $\mathrm{m}$ from the coastline in order to identify the lateral variations in coastal erosional landforms. Small changes in the route could occur with respect to the planned route due to the local topography or due to sea conditions. The latter could force the swimmers to move out from the coast for safety reasons. The navigation usually proceeded at a constant speed, ranging between 1 and $2 \mathrm{~km} / \mathrm{h}$, unless the swimmers encountered topographical obstacles or prominent geomorphological features. 

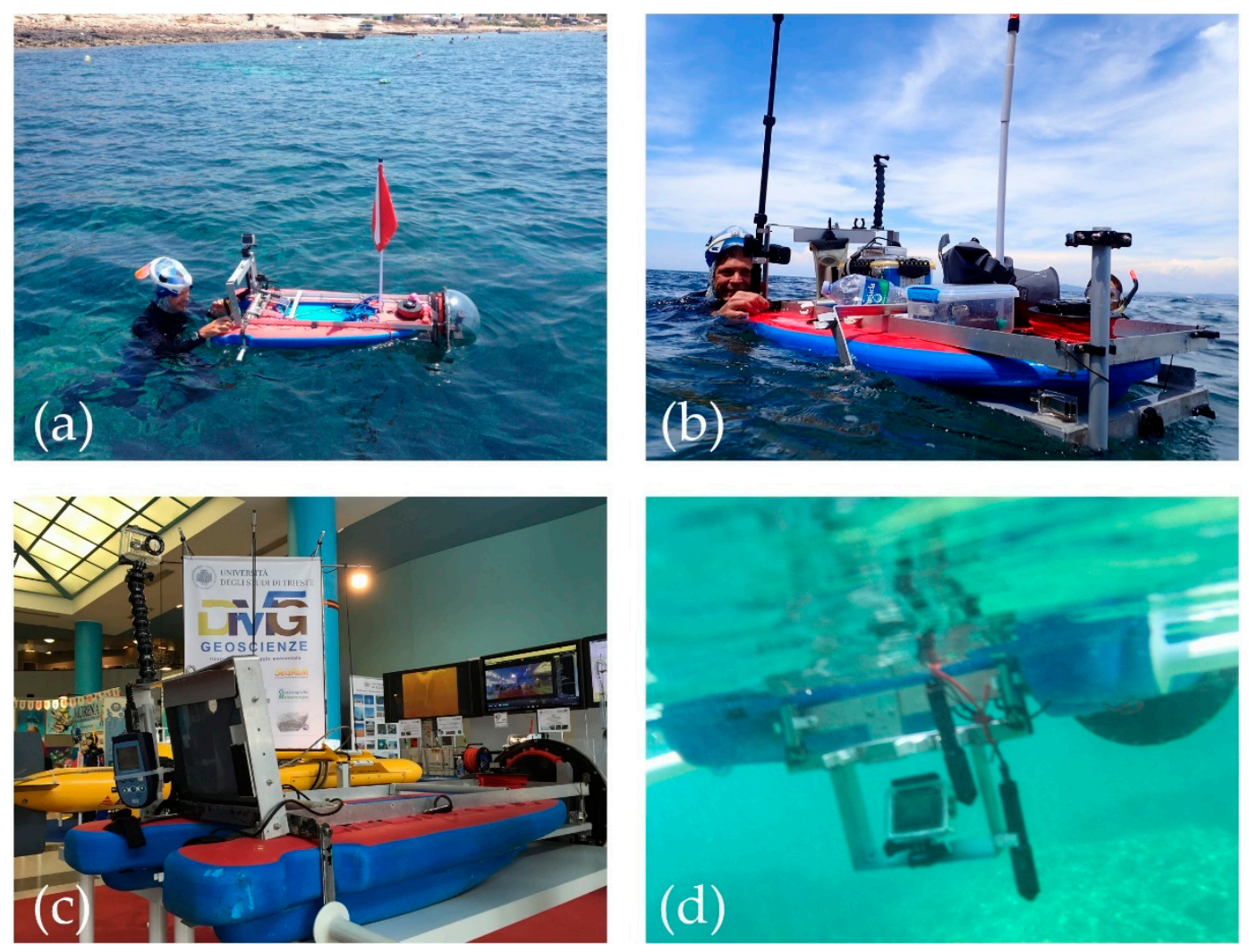

Figure 4. The raft, with cameras and other instruments, used during the snorkel surveys: (a) the raft used during the Maltese expedition; (b) the raft used at the Ansedonia promontory; (c) the raft during an exhibition; (d) the raft below the waterline.

Table 1. The routes and navigational parameters of the swim survey expeditions from 2014 to 2018 during the Geoswim expeditions.

\begin{tabular}{|c|c|c|c|c|c|c|c|}
\hline$\stackrel{\text { A }}{\text { Site No. }}$ & $\begin{array}{l}\text { B } \\
\text { Year }\end{array}$ & $\underset{\text { Location }}{\mathrm{C}}$ & $\begin{array}{c}\text { D } \\
\text { Number of } \\
\text { Surveyors }\end{array}$ & $\begin{array}{c}\text { E } \\
\text { Type of Rocks }\end{array}$ & $\begin{array}{c}\text { F } \\
\text { Type of } \\
\text { Survey }\end{array}$ & $\begin{array}{l}\text { G } \\
\text { Total Length of the } \\
\text { Route }(\mathrm{km})\end{array}$ & $\begin{array}{c}\mathrm{H} \\
\text { Days of } \\
\text { Survey }\end{array}$ \\
\hline $\begin{array}{c}1 \\
\text { (par. } 4.2 .1)\end{array}$ & 2014 & Egadi Islands (Italy) & 7 & $\begin{array}{l}\text { Calcarenites, dolomites, } \\
\text { limestones }\end{array}$ & Snorkelling & 63.5 & 7 \\
\hline (par. 4.2 .2$)$ & 2014 & Gaeta Promontory (Latium, Italy) & 4 & Hard limestones & Snorkelling & 3.1 & 1 \\
\hline $\begin{array}{c}(\text { par. } 4.2 .2) \\
3 \\
(4.2 .3)\end{array}$ & 2014 & $\begin{array}{c}\text { Circeo Promontory (Latium, } \\
\text { Italy) }\end{array}$ & 2 & Hard limestones & Kayaking & 8.1 & 1 \\
\hline $\begin{array}{c}4 \\
\text { (par. } 4.2 .4 \text { ) }\end{array}$ & 2015 & $\begin{array}{l}\text { Razzoli, Budelli, Santa Maria } \\
\text { (Sardinia, Italy) }\end{array}$ & 7 & Igneous rocks & Snorkelling & 26.3 & 3 \\
\hline $\begin{array}{c}5 \\
(\text { par. } 4.2 .5)\end{array}$ & 2015 & Capo Caccia (Sardinia, Italy) & 6 & $\begin{array}{l}\text { Soft to hard limestones, } \\
\text { marlstone, dolomites }\end{array}$ & Snorkelling & 14.6 & 2 \\
\hline $\begin{array}{c}6 \\
(\text { par. } 4.2 .6)\end{array}$ & 2015 & Tavolara (Sardinia, Italy) & 7 & $\begin{array}{c}\text { Dolomites and hard } \\
\text { limestones, igneous rocks }\end{array}$ & Snorkelling & 13.5 & 2 \\
\hline $\begin{array}{c}7 \\
(\text { par. } 4.2 .7)\end{array}$ & 2015 & Malta E (Malta) & 7 & $\begin{array}{l}\text { Soft to hard limestones, } \\
\text { calcarenites }\end{array}$ & Snorkelling & 19.5 & 3 \\
\hline $\begin{array}{c}8 \\
\text { (par. } 4.2 .8)\end{array}$ & 2016 & Mondello-Palermo (Sicily, Italy) & 5 & $\begin{array}{c}\text { Soft limestones, calcarenites, } \\
\text { hard limestones }\end{array}$ & Snorkelling & 6.4 & 1 \\
\hline $\begin{array}{c}9 \\
\text { (par. } 4.2 .9 \text { ) }\end{array}$ & 2018 & Ansedonia (Tuscany, Italy) & 7 & Hard limestones & Snorkelling & 3.4 & 2 \\
\hline TOTAL & & & 22 & & & 158.5 & 22 \\
\hline
\end{tabular}

\subsection{The Methodological Approach}

In this paper, we surveyed, measured, and mapped the erosional landforms described in Figure 3. The morphometric parameters of coastal landforms were measured using common field instruments, such as invar rods, compasses, stainless steel metric folding rules, and tape measures for submerged environments. Depths were measured with the aforementioned echosounders. The geographic positioning was taken with a Garmin Montana 650T GPS (Garmin Internatiol, Olath, KS, USA) and plotted on Google Earth maps (S1 in SM). All coordinates are expressed as latitude/longitude in the WGS84 reference system. Accuracy of location was within $10 \mathrm{~m}$. All measurements were taken in calm 
sea conditions, and were referred to mean sea level using the tide gauge data from the nearest tidal stations $[67,68]$, including corrections for atmospheric pressure at the time of measurement.

The tidal amplitude in the studied sites was evaluated from the Mediterranean database of the tidal prediction software developed at the Oregon State University [69]. The model is a state-of-the-art tidal model that uses most of the available satellite altimetric data: TOPEX/Poseidon, 531 cycles (all available data); TOPEX Tandem, 114 cycles (all available data); about 9000 data sites; ERS, about 20,000 data points ( $\mathrm{m} 2$ and $\mathrm{k} 1$ only), and in situ observations (e.g., tide gauges, shipborne ADCP). The model for the Mediterranean Sea has a resolution of $1 / 30(\sim 3.7 \mathrm{~km})$ and uses the GEBCO $1^{\prime}$ database for the bathymetric data. The model considers eight tidal components that account for $99 \%$ of the total tidal elevation.

Regarding MTNs and FTNs, we evaluated the extent of these landforms from field observations and the image dataset collected during the swim campaigns. The locations of tidal notches reported on maps correspond to sites where detailed measurements or specific observations were made. The morphometric parameters of MTNs and FTNs were estimated following the methods of [14,69-72], using a metric invar rod. Detailed morphometric parameters were measured considering the average notch width and depth, bottom reef depth, and presence of vermetid reefs [14]. These parameters represent a mean value of repeated measures with a small error bar (less than $\pm 0.10 \mathrm{~m}$ ). During the surveying period, uncertainties in the elevation measurements with respect to the sea surface or tidal level were negligible, because the tidal amplitude was $0.10 \mathrm{~m}$ in the study area [14].

The location of the erosional markers along the studied sectors was compared to local lithotypes using data from the geological literature-in particular, [73] for the Egadi Islands, [74] for the Circeo Promontory, and [75] for the Gaeta Promontory; for northern Sardinia, we used the webpage of the Sardinian regional geological service, and the webpage of the Tuscany regional geological service for the Ansedonia Promontory [76].

Lithologies can be conveniently divided into (1) Quaternary deposits, (2) soft limestone/calcarenite/marlstone, (3) medium limestone/carbonate breccia, (4) dolomite or hard limestone, and (5) igneous rocks. These lithologies correspond to increasing strength values, from very soft (1) to very hard (5), respectively. These characteristics of resistance have been mapped as a buffer zone from the coast inland.

Coastal morphotypes have been classified and mapped considering the topography of the emerged and the submerged parts of the coast (Figure 3). The morphotypes were recognized in the field and mapped using ArcGIS10 according to the methdoologies of [27] and $[28,29]$.

In order to describe the main morphologies, the nomenclature in [62] was used for the vermetid reefs.

\section{Results}

The route and navigational parameters of the swim survey expeditions are summarized in Table 1. The total length of the route was $158.5 \mathrm{~km}$, which was covered in 22 surveying days over 7 expeditions from 2014 to 2018. The results are not homogeneous, mainly because of technological and methodological improvements [24], weather and navigational conditions, and team composition. Moreover, due to adverse weather conditions, the promontory of Circeo was surveyed only with a kayak and with additional land surveys. Data have been divided into subsections, from 5.1 to 5.6, following the temporal subdivision described in Table 1.

In Table 2 are reported the lateral extent of MTNs, FTNs, and vermetid structures in the studied sites, the percentage of the length of sea level landforms with respect to the total length of the surveyed area, which data were used to process these data-such as videos or time-lapse images - the altitude of FTNs, and the method of evaluation (estimated from images/videos or measured). 
Table 2. Extent and altitude ASLASL of sea level change markers studied during the field campaigns.

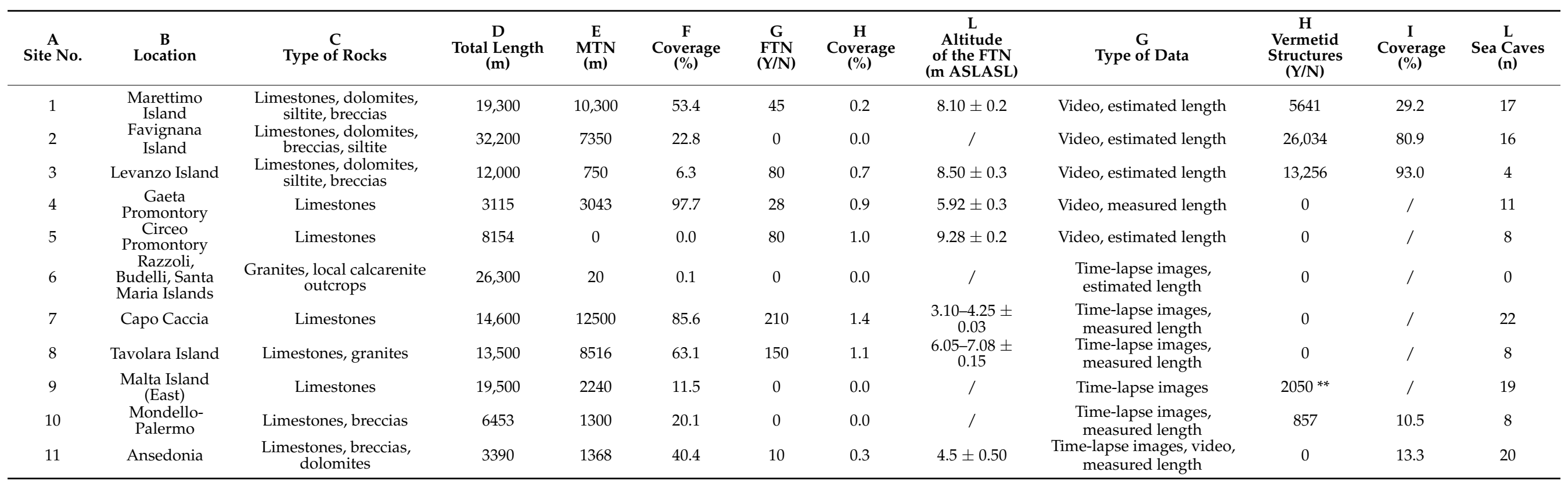




\subsection{Egadi Islands}

We surveyed the entire perimeter of the Egadi Islands, for a total length of $63.5 \mathrm{~km}$ (Table 1, Figure 5). In the following 3 subsections we describe the data collected in Marettimo (5.1.1), Favignana (5.1.2), and Levanzo (5.1.3).

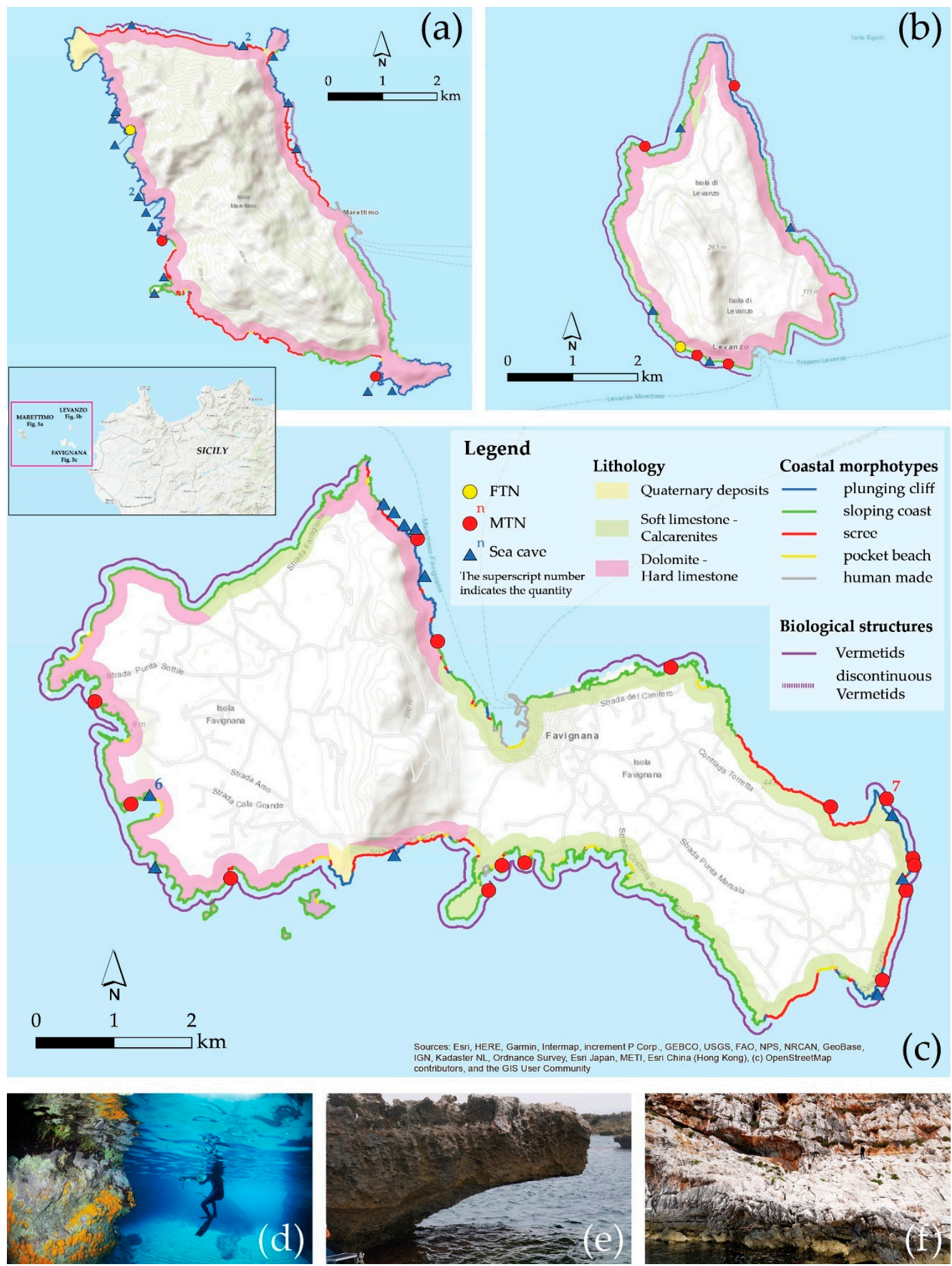

Figure 5. Maps of coastal morphotypes and the surveyed geomorphological and biological structures at (a) Marettimo, (b) Levanzo, and (c) Favignana; (d) Grotta della Pipa at Marettimo, (e) MTN at Favignana, and (f) FTN at Levanzo. 


\subsubsection{Marettimo Island}

The perimeter of the island is $19.3 \mathrm{~km}$. The route was covered in 3 days (Table 1). Rocky coasts occupy the entire perimeter of the island. Sloping coasts typify most of the southern coasts, while the western part of the island is characterized by very high plunging cliffs. The northern part of the island is dominated by coastal screes, while the eastern sector is more complex, with an interplay between plunging cliffs, alternating with screes and sloping coasts. In the latter sector there is also the village of Marettimo, representing the only urban area on the island. The southern promontory is fringed by plunging cliffs (Figure 5a).

The survey of the tidal notches in Marettimo highlighted that both MTNs and FTNs occur. MTNs develop along short sectors-roughly some tens of metres-in the locations reported in Figure $5 \mathrm{a}$, for a total length of $10.3 \mathrm{~km}$. FTNs occur at two sites along the northwestern coast of Marettimo, for a total length of $45 \mathrm{~m}$ (Table 2, Figure 5a).

We surveyed 17 sea caves all around the island (Figure 5a), most of them developed in stromatolitic or limestone dolomites along plunging cliffs on the western side of the island. These caves generally developed along vertical or subvertical fractures or faults. Twelve of them were previously known and published by [77], while four of them are here reported for the first time. Seven of the sea caves reported in Figure 5a have a local name due to their scenic value. No sea level change markers occured within the surveyed caves.

No MSPs or FMTs were found in the southwestern sector of the island, although some Tyrrhenian deposits were reported [78].

The island is rimmed by vermetid reefs in its northern part only. Over the rest of the island, the coasts are colonized by Lithophyllum rims and vermetid encrustations.

\subsubsection{Favignana Island}

Favignana is the largest island of the Egadi Islands. It is $19 \mathrm{~km}^{2}$ in area and has a perimeter of $32.2 \mathrm{~km}$, which was surveyed in five surveying days. The island's coastline consists mainly of sloping coasts $(66 \%)$, with a slope from $5^{\circ}$ to $45^{\circ}$, and plunging cliffs $(17 \%)$, mostly located along the eastern sector. The remaining coastal stretches of the island are composed of screes, pocket beaches, and built-up coast, the latter represented by the town of Favignana.

MTNs in Favignana are widely spread both in microcrystalline dolomites and in calcarenites, and their development is almost continuous, with an average size of $0.70 \mathrm{~m}$ in width and $1.00 \mathrm{~m}$ in depth. They are highly continuous on the eastern side of the island. Tidal notches are smaller at sloping coasts, with a width of $40 \mathrm{~cm}$ and a depth of $50 \mathrm{~cm}$.

No MSPs were found, while FMTs were found along more than $3 \mathrm{~km}$ of coastline in both the northern and southern sectors of the island (Figure 5c).

We surveyed 16 sea caves (Table 2) that were cut in microcrystalline dolomites and calcarenites and situated along the plunging cliffs skirting the eastern side of the island. Three of them were discussed in [77], while thirteen are here reported for the first time. We also discovered a new cave, which we called Geoswim; it is characterized by an entrance at less than $1 \mathrm{~m}$ in height ASL, and the sea bottom lays at about $2 \mathrm{~m}$ BSL. Inside the cave, three corridors, each of them parallel to one another and to the coastline, elongate for about $70 \mathrm{~m}$ each. In the inner part of the three corridors, we found small gravel beaches.

The most relevant bioconstruction bordering the island is produced by vermetids (Dendropoma cristatum) that developed on the sloping coast and created reefs that increase continuously up to 2 metres from the coastline. This type of bioconstruction only develops at the mean sea level, and thus constitutes a reliable indicator of the relative sea level change $[9,79,80]$. Vermetid reefs were found in Favignana, on the northwestern coast between Faraglione Point and Ferro Point, the southwestern coast between Fanfalo Point and Burrone Point, and near Vituzzo.

Lithophyllum byssoides rims that developed along the plunging cliffs, and where the hydrodynamism is particularly intense, are less common. They contribute to the construction of a limestone sidewalk ("trottoir"), which plays an important protective role for the cliff. 


\subsubsection{Levanzo Island}

Levanzo is the smallest of the Egadi Islands, with a perimeter of $12 \mathrm{~km}$, which was surveyed in one day. It is completely formed from dolomites and dolomitic limestone, and it is mainly composed of plunging cliffs (69\%) in the north, northeast, and northwest sectors of the island. The southern sector is characterized by an alternation of sloping coasts and screes.

MTNs occur at three sites on the island, for a total length of $0.75 \mathrm{~km}$, while FTNs occur at one site on the northwestern side of the island, for a total length of $80 \mathrm{~m}$.

There are no MSPs on Levanzo, while FMTs occur on both the eastern and western sides of the island, at an elevation of about $8.50 \mathrm{~m}$ ASL, sometimes associated with FTNs.

We surveyed only four sea caves (Figure $5 b$ ) cut into plunging cliffs; two of them were discussed in [77].

Small vermetid reefs could be found only along the northern and southwestern coasts.

\subsection{Gaeta and Circeo Promontory}

The promontory of Monte Orlando (Gaeta, Latium, Italy) is $171 \mathrm{~m}$ in height, while the coastline is $2.2 \mathrm{~km}$ long, and it was surveyed in one day (Table 1, Figure 6a). It is cut from Mesozoic limestones, and is entirely composed of rocky coasts-in particular, plunging cliffs exposed to southern winds. These cliffs are up to $70 \mathrm{~m}$ in height. The depth below the cliffs ranges from $10 \mathrm{~m}$ to $18 \mathrm{~m}$ BSL. Part of the data were published in $[14,55]$.
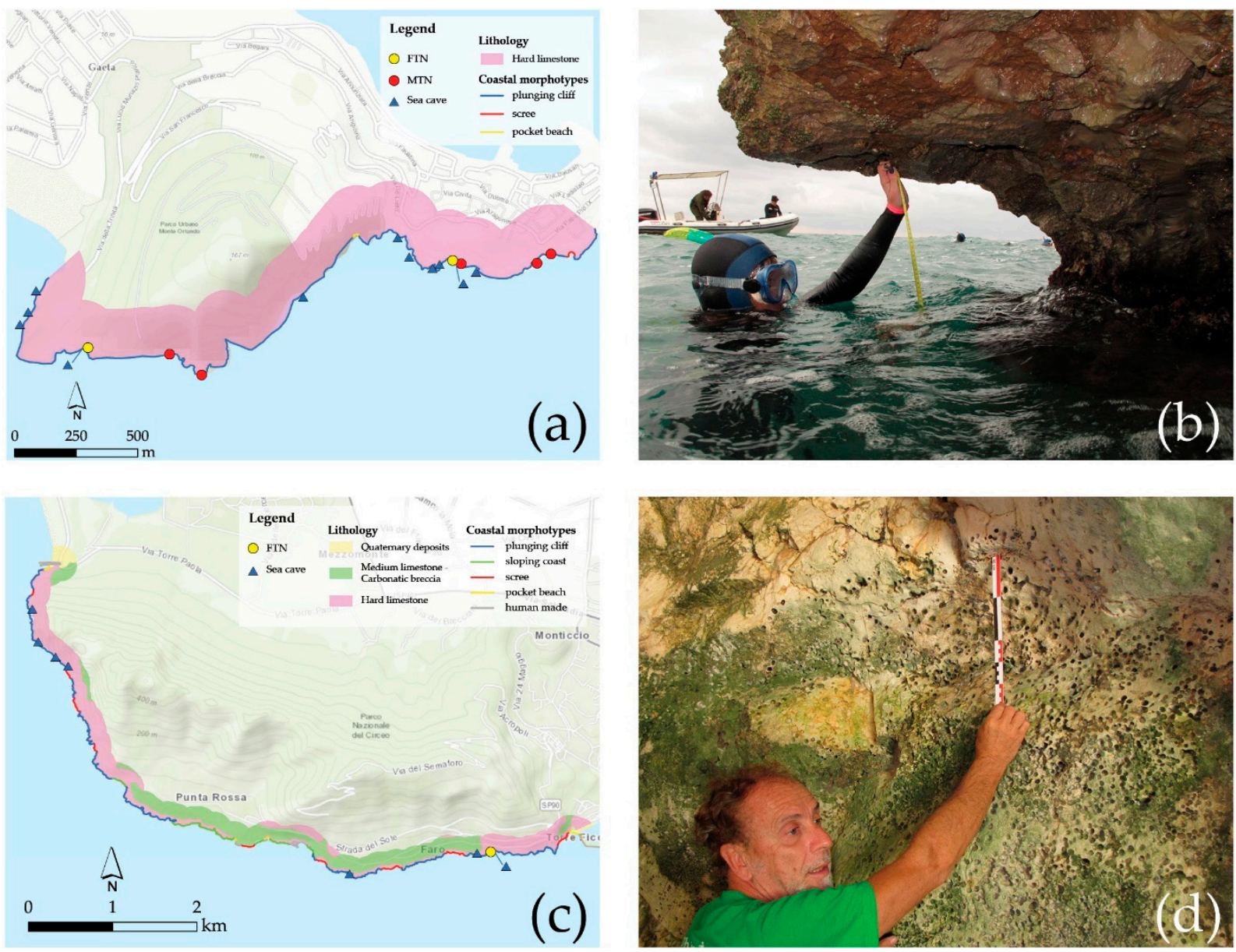

Figure 6. (a) Maps of coastal morphotypes and surveyed geomorphological structures at Monte Orlando (Gaeta), (b) MTN at Monte Orlando (Gaeta), (c) maps of the surveyed geomorphological structures at Circeo promontory, and (d) Lithophaga lithophaga holes inside the FTN at Grotta delle Capre (Circeo promontory). 
MTNs are almost continuous along the promontory of Monte Orlando. They were measured within the Grotta del Turco, and are $0.35 \mathrm{~m}$ high and $0.40 \mathrm{~m}$ deep (Figure $6 \mathrm{~b}$ ). Along the entire promontory, MTN size remains stable, with the concavity ranging from $0.35 \mathrm{~m}$ to $0.40 \mathrm{~m}$. At one site only, an FTN occurs with a depth of $1.20 \mathrm{~m}$.

We surveyed 10 sea caves all around the promontory (Figure 6a), most of them developed in Mesozoic limestone. These caves generally developed along vertical or subvertical fractures or faults. The most famous is Grotta del Turco-85 m in height, $100 \mathrm{~m}$ in width. The maximum depth is about $6 \mathrm{~m}$ at the entrance. Some sea caves surveyed have a local name due to their scenic and tourist importance.

A cave developed along limestone beds that rise from vertical to $60^{\circ}$ and facilitated the widening at another site, where a fault passes through. The latter was sealed by continental breccias older than MIS 5.5. On this deposit, there are also rounded pebbles and cobbles that are cut to form a marine terrace at $5.10 \mathrm{~m} \mathrm{ASL}$ and, while at the inner margin, an FTN occurs. The age is the same as that of the FTN measured within the Grotta del Turco, as measured in [55] at $5.9 \mathrm{~m}$ ASLASL and aged to MIS 5.5.

Near Grotta del Turco, three fractures, in a northern direction and following the local morphology, cut the entire cliff from the cliff top to the cliff toe below the sea level. One of these fractures, $0.80 / 0.90 \mathrm{~m}$ in width, was surveyed for at least $50 \mathrm{~m}$ within the promontory, and possibly crosses the promontory. At one site, Chthamalidae colonies occur in shape of stalactites. Overall, Chthamalidae and Patella caerulea are uncommon along the promontory.

A Lithophyllum sp. structure occurs along the entire promontory. It is $1 \mathrm{~m}$ in thickness at the Grotta del Tuono, while it is tighter outside the caves.

The promontory of Circeo (Latium, Italy) is $541 \mathrm{~m}$ in height, while the coastline is $2 \mathrm{~km}$ long, and it was surveyed in one day (Table 1, Figure 6c). It is entirely composed of rocky coasts cut from Mesozoic limestones. The cliffs are exposed to southern winds. The cliffs are up to $50 \mathrm{~m}$ in height. The depth below the cliffs ranges from $2 \mathrm{~m}$ to $18 \mathrm{~m}$ BSL.

The MTN at the Promontory of Circeo is completely absent (Table 2), but along the entire perimeter of the promontory there is a large Lithophyllum trottoir up to $0.40 \mathrm{~m}$ ASL in depth. Close to sea level, colonies of Balanidae and Mytilus galloprovincialis are common in the area. Regarding the latter, it is not clear if they are related to the occurrence of freshwater, because we did not use the same swimming method as in the other sites.

The promontory hosts several sea caves containing Tyrrhenian fauna, previously described in $[80,81]$ at an elevation ranging between $5 \mathrm{~m}$ ASL and $8 \mathrm{~m}$ ASL. In particular, an MIS 5.5 tidal notch occurs within the Grotta delle Capre-a sea cave with prehistoric deposits, dated back to the middle Palaeolithic [81]. The FTN begins at $9.28 \pm 0.2 \mathrm{~m}$, and it occurs throughout almost the entire cave. The width ranges between $0.32 \mathrm{~m}$ and $0.25 \mathrm{~m}$-the smallest in the central Mediterranean area (mean, $0.28 \mathrm{~m}$ )—with a depth ranging between $0.20 \mathrm{~m}$ and $0.12 \mathrm{~m}$ (mean, $0.16 \mathrm{~m}$ ), while maximum local tide amplitude is $0.369 \mathrm{~m}$. Several other caves occur along the promontory, such as Grotta Guattari, with Neanderthal skulls [82] Riparo Blanc, with remains of Mesolithic Age meals; Grotta del Fossellone, with Senegalese fauna dating back to MIS 5.5; and Grotta Breuil, with fossil fauna of the middle Pleistocene and human remains dating back to the upper Palaeolithic.

\subsection{North Sardinia}

We surveyed the entire perimeter of the islands of Razzoli, Budelli, and Santa Maria, which are part of the Maddalena archipelago (5.3.1.); the promontory of Capo Caccia (5.3.2.); and the island of Tavolara (5.3.3.), for a total length of $54.4 \mathrm{~km}$ (Table 1) surveyed in 7 days. The coastal morphotypes and the locations of the surveyed coastal erosional landforms relative to the sea level are reported in Figure 7a-c. 

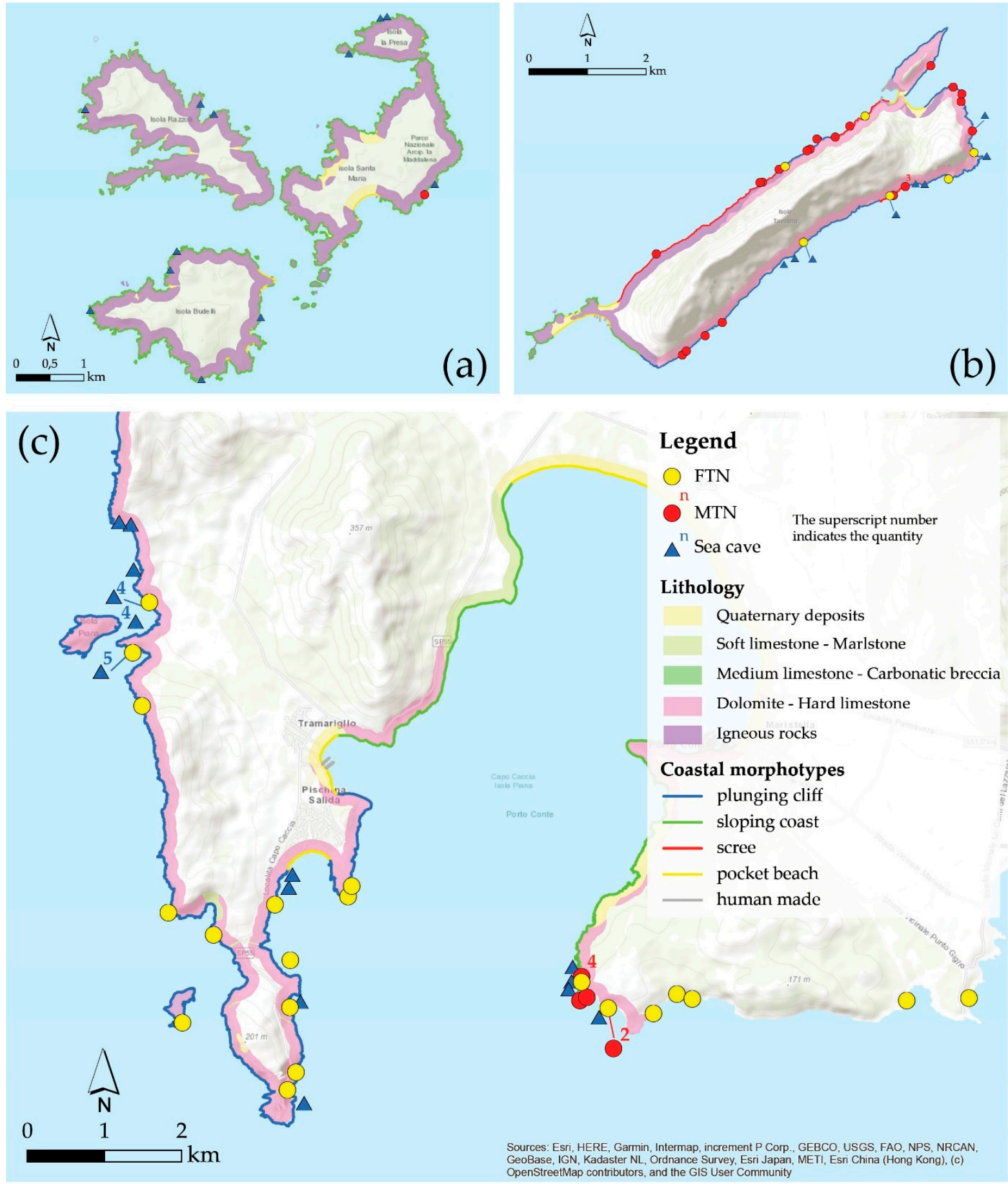
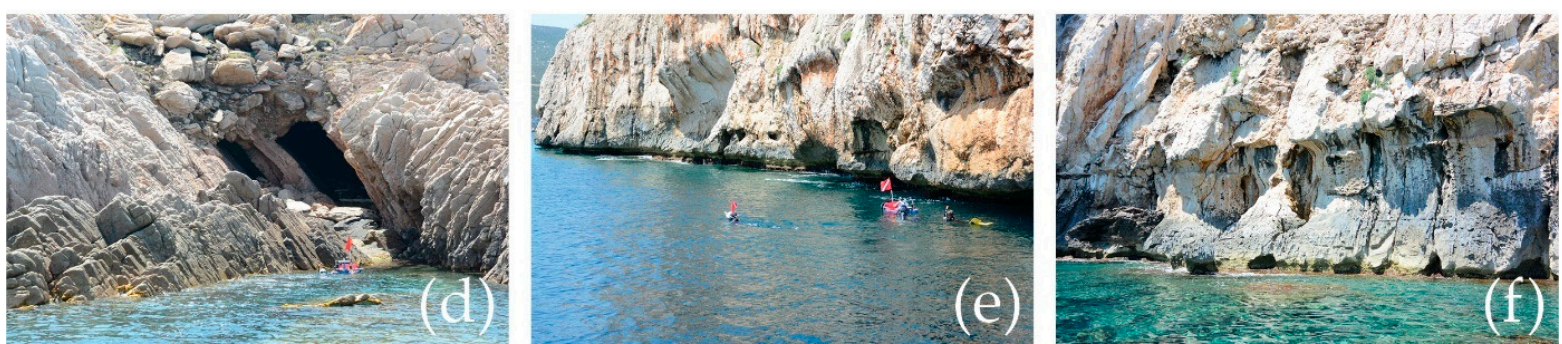

Figure 7. Maps of coastal morphotypes and surveyed geomorphological structures at (a) Razzoli, Budelli, and Santa Maria islands, (b) Tavolara, and (c) Capo Caccia; (d) sea cave at Razzoli, (e) MTN at Capo Caccia; (f) MTN and FTN near a sea cave at Tavolara. 
5.3.1. Razzoli, Budelli, and Santa Maria Islands (Maddalena Archipelago, Northeastern Sardinia)

These islands are entirely made from Palaeozoic intrusive magmatic rocks. The coastline is highly indented, with plunging cliffs, sloping coasts, and small pocket beaches, but the morphotypes were not mapped because of the high complexity of the coastline.

Patella caerulea, Chthamalus, and red coralline algae "trottoirs" of about $25 \mathrm{~cm}$ in width, were recognized at the sea level together with Dendropoma sp., Serpulidae from $2 \mathrm{~m} \mathrm{BSL}$, Lithophyllum from up to $0.6 \mathrm{~cm}$ ASL, and Patella ferruginea from SL to $0.40 \mathrm{~m}$ ASL.

An MTN was recognized at one site at an aeolianite outcrop (Figure 7a), with a depth and width of about $0.5 \mathrm{~m}$, while no FTNs were surveyed. MSPs and FMTs were not identified along the studied coastline.

\subsubsection{Capo Caccia (Northwestern Sardinia)}

Capo Caccia is a limestone promontory in the northwestern part of Sardinia. The Capo Caccia promontory mainly consists of plunging cliffs, with some small pocket beaches and very short sectors of coastal screes (Figure 7c).

MTNs occur almost all over the coastal sector, while FTNs are up to $210 \mathrm{~m}$ long. No MSPs or FMTs occur in the studied sectors. We identified and surveyed 22 sea caves.

\subsubsection{Tavolara Island (Northeastern Sardinia)}

Tavolara is a northeast-elongated island, about $6.8 \mathrm{~km}$ in length and about $1.7 \mathrm{~km}$ in width. It is mainly composed of Mesozoic limestones, while short sectors of its western part are made from Hercynian magmatic intrusive rocks, with some small continental and marine deposits, mostly MIS 5.5 in age. The limestone section is almost entirely cut into plunging cliffs and short sectors of screes. In the northern part of the island there is a pocket beach that we did not survey since it is a military zone, while the southernmost sector of the island is fringed by low-lying rocky coasts and pocket beaches.

MTNs were measured at 22 sites along the eastern part of the island, where they are almost continuous along $8.5 \mathrm{~km}$ of coastline (Table 2). MTNs occur along $150 \mathrm{~m}$ of coastline. Eight sea caves were surveyed on the limestone section of the island (Figure $7 \mathrm{~b}$ ).

The mesolittoral zone displays a variety of organisms, including abundant red coralline algae, Lithophyllum sp., green algae, Cystoseira terraces, and large populations of Patella rustica and Patella ferruginea occupying the upper fringe. The occurrence of the sublittoral Spondylus gaederopus at ca $50 \mathrm{~cm}$ BSL is noticeable, given its common occurrence in MIS 5.5 outwash deposits.

\subsection{The Maltese Islands (Eastern Malta)}

We report here the results of the survey of four sites situated along the northeastern coast of Malta, totalling a coastal survey of $8.37 \mathrm{~km}$ : Ahrax, Qawra Point, Pembroke, and Delimara (Hofra l-Kbira). Rocky coasts characterize $100 \%$ of the surveyed shorelines (Figure 8). 

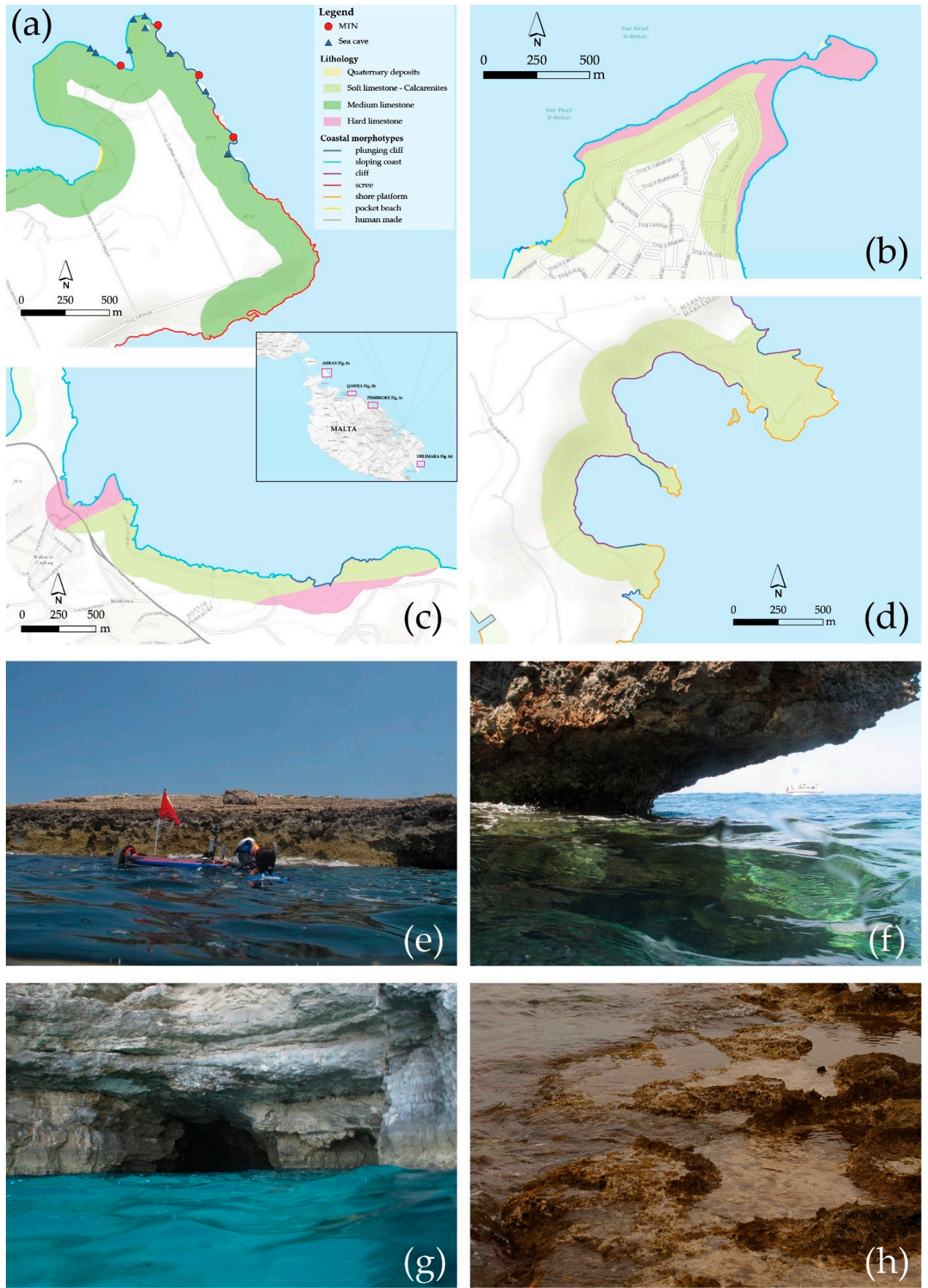

Figure 8. Maps of coastal morphotypes and surveyed geomorphological structures at (a) Aћrax (Mellieha), (b) Qawra, (c) Pembroke, and (d) Delimara (Xrobb l-Ghagin, Hofra l-Kbira); (e) sloping coast with coastal boulders at Aћrax; (f) MTN at Marfa Ridge; (g) sea cave at Marfa Ridge; (h) vermetid terrace near Pembroke. 


\subsubsection{Ahrax (Mellieha)}

The total stretch of coast we surveyed is $2.47 \mathrm{~km}$. The Ahrax site consists of a northeastexposed linear coastline and two promontories (north-north-northwest-oriented) along the eastern tip of Marfa Ridge (Malta), and faces the structurally faulted Comino Channel ( $5 \mathrm{~km}$ wide, $7 \mathrm{~km}$ long) situated between the islands of Malta and Comino. The survey at Ahrax $(\sim 2.47 \mathrm{~km})$ covered a coastal terrain characterized by fault-elevated vertical plunging cliffs in Upper Coralline Limestone (UCL, Tal-Pitkal and Mtarfa member) along both the A rax and White Tower peninsulas (maximum elevation, $\sim 25 \mathrm{~m}$ ASL) and a sheltered north-facing col in between the two peninsulas (depth $\sim 7 \mathrm{~m}$ ). Ahrax terrain is typified by a range of erosional and depositional signatures from extreme-wave events such as onshore clustered and imbricated boulders, surface sockets, scarps, ramps, and submerged boulders $[29,83,84]$.

Notch-like features occur along the entire stretch, but at four sites MTNs are prominently hewn out. At two sites, the maximum depth is $2.5 \mathrm{~m}$. We did not survey FTNs. No MSPs or FMTs were discovered in the area. In the area we surveyed nine sea caves (Figure 8a); one of them is a post-Miocene collapsed sinkhole on the Ahrax Peninsula up to $\sim 10 \mathrm{~m} \mathrm{ASL}$, reported in [85]. An MTN occurs within the sinkhole.

The vermetid crusts are formed by Dendropoma sp. The seaward accretion of vermetid reef is a maximum of $1.0 \mathrm{~m}$, while the thickness is about $50 \mathrm{~cm}$.

\subsubsection{Qawra}

The total stretch of the surveyed coast was $2 \mathrm{~km}$. The surveyed site at the Qawra Peninsula $(\sim 2 \mathrm{~km})$ covered a low rocky coastline in Lower Coralline Limestone (LCL, Xlendi member), and which outcrops at sea level as a sub-horizontal terraced platform and is capped by a low, overlying cliff ( $3-5 \mathrm{~m}$ in height) in Lower Globigerina Limestone (LGL). Erosional and depositional signatures from extreme-wave events-such as jointbounded and imbricated boulders, elongated detachment scarps, sediment-filled sockets, and a conjugate network of joints-are present in lithologies and scattered along the northnortheast-oriented terraced coast, to a maximum elevation of $\sim 10 \mathrm{~m}$ ASL. The seaward tip of the peninsula, apart from being the most northeast-exposed part of the site, is totally composed of coarse-grained LCL (Xlendi member) lithology, and partially disconnected from land access due to the semi-submerged conditions of its connecting isthmus with the landward side of the peninsula. The coastal terrain is relatively more low-sloping, and a cluster of north-facing boulders are distributed at an average elevation of 1-3 m ASL.

A well-carved MTN has developed at Qawra point, where the coast is a plunging cliff. We did not observe any FTNs in this survey. No MSPs or FMTs were discovered in the area. In the area we surveyed one sinkhole at Qawra point (Figure 8b).

The vermetid crusts are formed by Dendropoma sp. and Vermetus triquetrus, as previously reported in [84]. The seaward accretion of vermetid reef is $1.0 \mathrm{~m}$, while the thickness is about $30-40 \mathrm{~cm}$.

\subsubsection{Pembroke}

The Pembroke survey covered a $2.12 \mathrm{~km}$ stretch from the eastern end of Bahar ićCaghaq Bay to the western limits of the coast overlooked by Madliena Tower (Pembroke). This site represents the eastern limit of the island's great fault system, in which a series of norrtheast-southwest faults run transversally through the coast, creating a sequence of lithological outcrops that alternate from LCL (Xlendi member) to LGL and back to LCL (Xlendi member) in a west-east direction along the coast. The northeastern exposure of the site, coupled with the presence of intensely jointed LGL, has resulted in the development of an elongated scatter of joint-bounded boulders, detachment scarps, and sediment-filled sockets along the low-lying shores of this area.

Notch-like features occur along the entire stretch, but at four sites MTNs are very developed. At two sites, the maximum depth is $2.5 \mathrm{~m}$. FTNs were not observed in this part of the survey. 
No MSPs or FMTs were discovered in the area. However, near the Qawra Tower, a supratidal MSP at about $1.0 \mathrm{~m}$ ASL has developed along a length of ca. $600 \mathrm{~m}$.

The vermetid crusts are formed by Dendropoma sp., Vermetus triquetrus, and Neogoniolithon brassica-florida, as previously reported in [86]. We confirm data reported by the authors, and the length of vermetid reef is $70 \mathrm{~m}$, while the thickness is about $30 \mathrm{~cm}$.

\subsubsection{Delimara (Xrobb 1-Ghagin, Hofra 1-Kbira)}

The total stretch of the surveyed coast was $2.14 \mathrm{~km}$ (Figure 8d). The Delimara survey covered the southeast-oriented coastline $(2.14 \mathrm{~km})$ around one of two sub-circular embayments present at the Xrobb l-Ghagin area, known as Hofra il-Kbira, which is enclosed between the promontories of Ras il-Fenek and Xrobb-l-Ghagin Point. The landward part of the bay is in relatively softer Middle Globigerina Limestone (MGL), while more resistant outcrops of a $3-5^{\circ}$ dip were Upper Globigerina Limestone (UGL) outcrops at both promontories. The morphogenesis of the surveyed bay is attributed to the presence of an ancient drainage line that converged into the bay [87]. The combination of fluvial erosional notches at the exposed unit of UGL and selective marine erosion created a retrogressive erosion of the dipped UGL, and subsequently led to the inland semi-circular removal of the MGL beds.

We did not encounter MTNs or FTNs in this embayment and found neither MSPs nor FMTs. A wide sea cave occurs, $50 \mathrm{~m}$ in length, $3 \mathrm{~m}$ in width, and $1.5 \mathrm{~m}$ ASL and BSL.

\subsection{North Coast of Palermo}

In this section we report the results of the survey of two rocky stretches between Addaura and Arenella Harbour (Palermo, Sicily), with respective lengths of $371 \mathrm{~m}$ and $534 \mathrm{~m}$ (Figure 9a). At Arenella we collected detailed measurements on the morphometric parameters of MTNs at 25 sites.

The area is affected by east-west-, north-south-, and north-northeast-south-southwesttrending extensional fault systems with predominant vertical displacement. The coast is cut into Mesozoic limestone, and is mainly composed of sloping coasts. A 390-m-long pocket beach, called Vergine Maria, and a human-made embankment lie in the midsection between the start and end points of the survey.

We measured MTNs at nine sites, together with 25 other detailed measurements over about $500 \mathrm{~m}$ (Figure 9a), in order to detail the site of Arenella. In the study area, the MTN width ranges between 0.30 and $0.60 \mathrm{~m}$, and its depth was measured between 0.40 and $2.20 \mathrm{~m}$. At Arenella, the MTN width ranges between 0.39 and $0.52 \mathrm{~m}$, and lies at a depth between $0.65 \mathrm{~m}$ and $2.20 \mathrm{~m}$. The width is usually smaller than the MTN, ranging between $0.37 \mathrm{~m}$ and 0.50 , with a mean value of $0.44 \mathrm{~m}$. Here, the mean tide is 0.37 , as reported previously in [14]. FTNs associated with Lithophaga lithophaga holes were detected at an elevation ranging between 3 and $7 \mathrm{~m}$ ASL. In the conglomerate outcrops the notch base is usually 0.10 to $0.15 \mathrm{~m}$ higher than limestone notches. A submarine spring occurs near the deeper FTNs.

No MSPs were recognized, while a small FMT with an annexed FTN of about $10 \mathrm{~m}$ in length was recognized.

We surveyed eight sea caves along the surveyed sectors; two of them contain MIS 5.5 deposits and fossils.

In the tidal zone, biological structures are almost continuous, and consist of vermetid bioconstructions with a thickness ranging between $0.5 \mathrm{~m}$ and $0.12 \mathrm{~m}$. At some sites they are replaced by large balanids.

\section{Detailed Measurements in Palermo}

We surveyed a stretch of coast of $311 \mathrm{~m}$ in Palermo (Figure 10). Here we measured the morphometric parametres of FTNs at 25 sites (Table 3) during a sunny day with no waves. FTNs appear very well carved. 

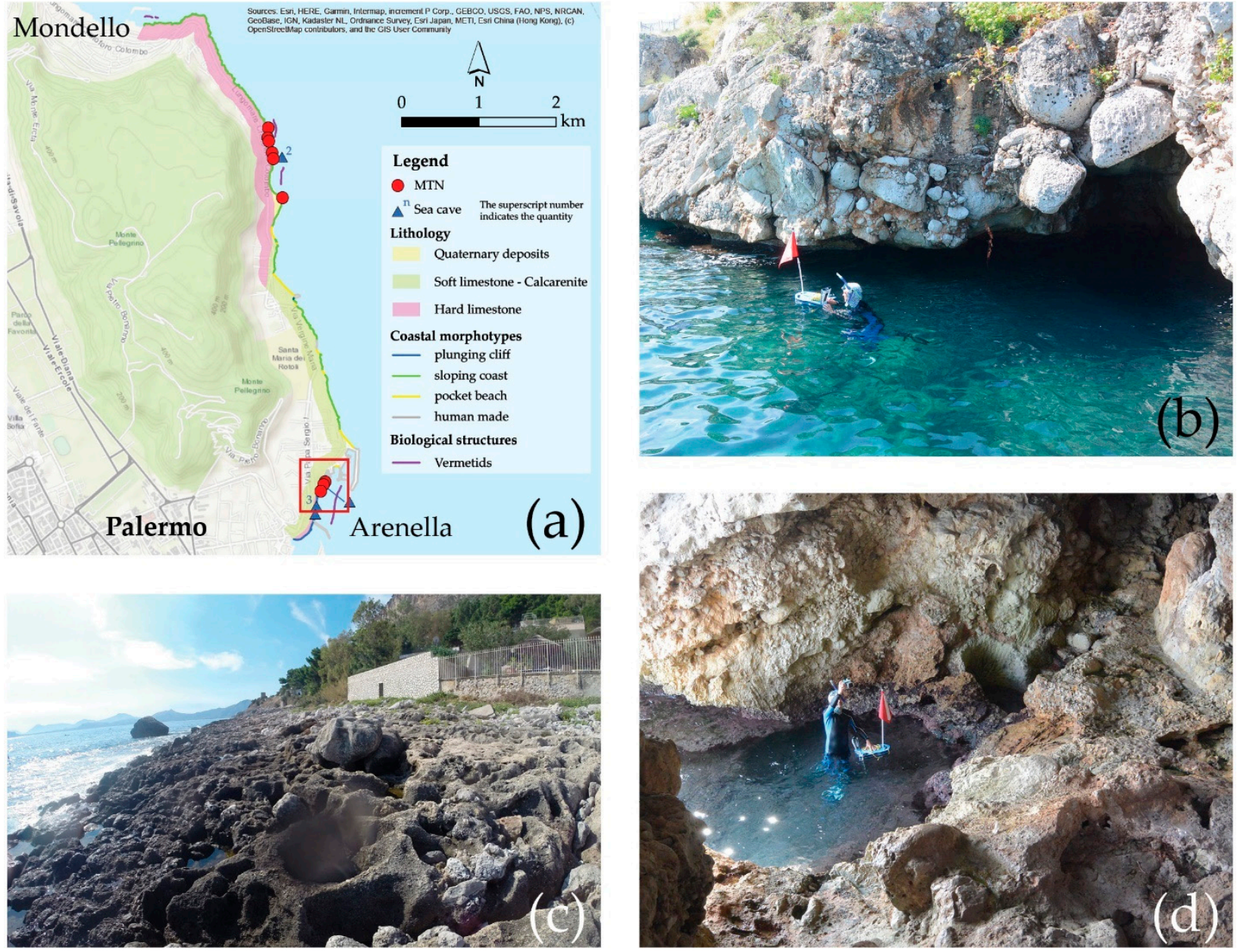

Figure 9. (a) Maps of coastal morphotypes and geomorphological and biological structures on the northern coast of Palermo (Sicily, Italy). Inside the red square, one measure every $20 \mathrm{~m}$ of coast was carried out; (b) tidal notch at the entrance of a sea cave; (c) sloping coast; (d) sea cave cut in conglomerate.

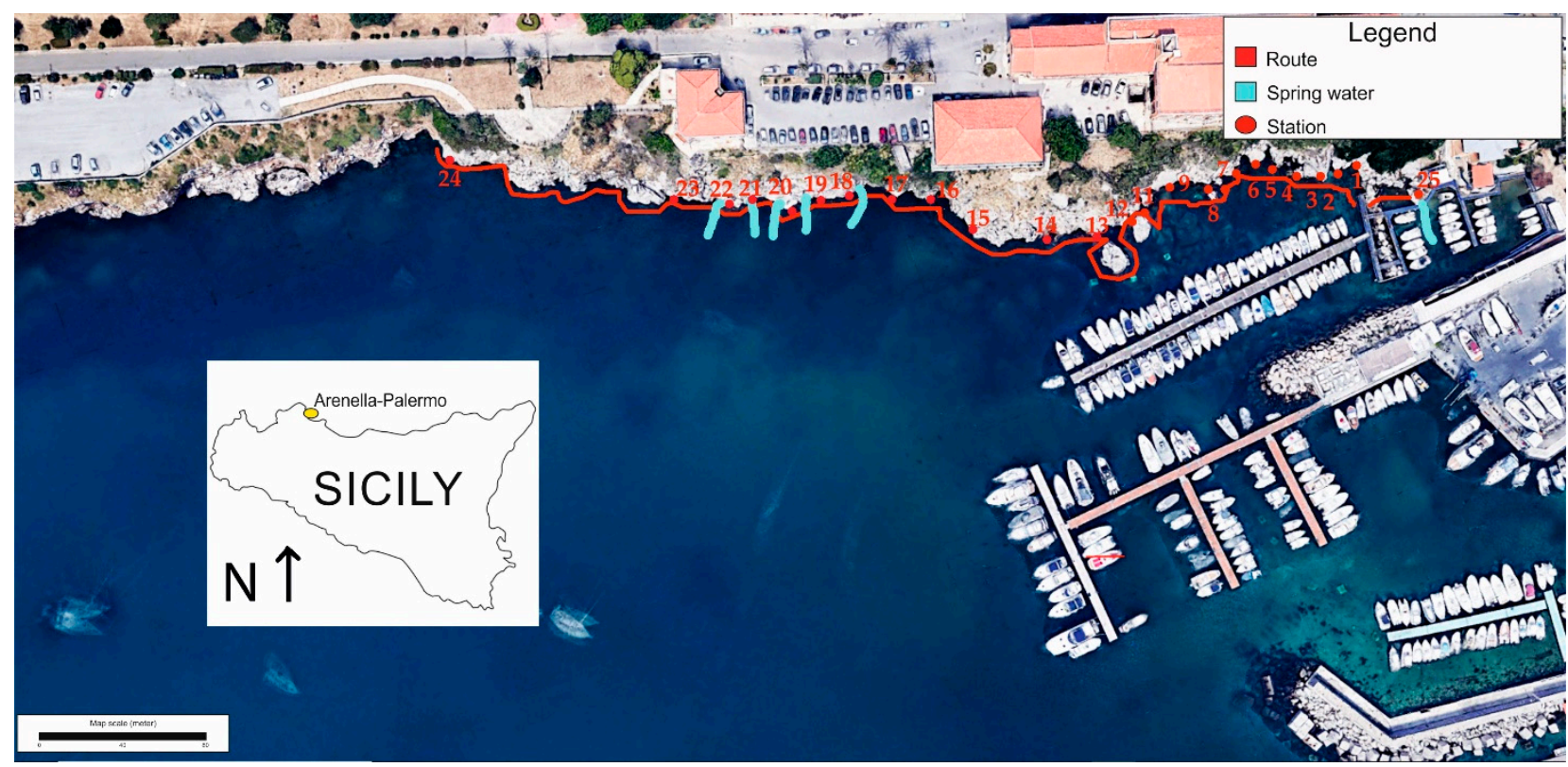

Figure 10. Location of 25 FTN sites along a 311-m stretch of coast in Palermo. 
Table 3. The morphometric parametres of MTNs in the short stretch at the Arenella harbour (Palermo).

\begin{tabular}{|c|c|c|c|c|c|c|c|c|}
\hline Site & $\begin{array}{l}\text { Photo } \\
\text { No. }\end{array}$ & $\begin{array}{l}\text { MTN Width } \\
(\mathrm{cm})\end{array}$ & $\begin{array}{c}\text { MTN } \\
\text { Depth (cm) }\end{array}$ & $\begin{array}{l}\text { MTN Bottom } \\
\text { Depth (cm) }\end{array}$ & $\begin{array}{l}\text { Depth of Cliff } \\
\text { Toe }(\mathrm{cm})\end{array}$ & $\begin{array}{l}\text { Freshwater } \\
\text { Spring (Y/N) }\end{array}$ & Lithology & Notes \\
\hline 1 & 1 & 39 & 78 & 38 & 112 & $\mathrm{~N}$ & limestone & Pebbles $1-2 \mathrm{~cm}$ in size at submerged cliff toe. \\
\hline 2 & - & 41 & 65 & 65 & 139 & $\mathrm{~N}$ & limestone & Pebbles $10 \mathrm{~cm}$ in size at submerged cliff toe. \\
\hline 3 & 2 & 43 & 174 & 76 & 165 & $\mathrm{~N}$ & limestone & - \\
\hline 4 & - & 45 & - & - & - & $\mathrm{N}$ & limestone & - \\
\hline 5 & - & 44 & 78 & 84 & 147 & $\mathrm{~N}$ & limestone & - \\
\hline 6 & - & 42 & 104 & 95 & 260 & $\mathrm{~N}$ & $\begin{array}{l}\text { limestone } \\
\text { conglomerate }\end{array}$ & $\begin{array}{l}\text { MTN base lays } 0.12 \mathrm{~m} \text { ASL. Dissolution forms and conglomerates within the } \\
\text { notch. }\end{array}$ \\
\hline 7 & - & 52 & 73 & 139 & 188 & $\mathrm{~N}$ & conglomerate & Blocks $10 \mathrm{~cm}$ in size at the sea bottom due to recent collapse phenomena. \\
\hline 8 & - & 50 & 73 & 57 & $>200$ & $\mathrm{~N}$ & conglomerate & The base of the MTN lays $1 \mathrm{~cm}$ BSL. \\
\hline 9 & - & 48 & 150 & 67 & $>200$ & $\mathrm{~N}$ & limestone & The base of the MTN lays $5 \mathrm{~cm}$ ASL. \\
\hline 11 & - & - & - & - & - & $\mathrm{N}$ & limestone & $\begin{array}{l}\text { A stack occurs just in front of the site, and could be responsible for the } \\
\text { absence of MTN. }\end{array}$ \\
\hline 12 & - & - & - & - & - & $\mathrm{N}$ & $\begin{array}{l}\text { limestone and } \\
\text { conglomerate }\end{array}$ & Submerged platform. \\
\hline 13 & - & 37 & 95 & 18 & 300 & $\mathrm{~N}$ & conglomerate & $\begin{array}{l}\text { Small emerged platform, cut in limestones and conglomerates. The presence } \\
\text { of boulders distorts the depth of the sea bed. }\end{array}$ \\
\hline $\begin{array}{l}14 \\
15\end{array}$ & $\stackrel{3}{4-5}$ & $\begin{array}{l}45 \\
42\end{array}$ & $\begin{array}{c}70 \\
130\end{array}$ & $\begin{array}{l}100 \\
75\end{array}$ & $\begin{array}{l}300 \\
350\end{array}$ & $\stackrel{\mathrm{N}}{\mathrm{N}}$ & $\begin{array}{l}\text { conglomerate } \\
\text { conglomerate }\end{array}$ & $\begin{array}{l}\text { Conglomerates and platform } 20 \mathrm{~cm} \text { higher than mean tide } \\
\text { The base of the MTN is } 15 \mathrm{~cm} \text { ASL. }\end{array}$ \\
\hline 16 & $6-7$ & $\sim 45$ & - & - & - & $\mathrm{N}$ & conglomerate & Large and small barnacles within the MTN. Platform collapse, presence of \\
\hline 17 & $8-9$ & 49 & 137 & 118 & 300 & $\mathrm{~N}$ & conglomerate & $\begin{array}{l}\text { boulders, no } \text { The base of } \text { MTN is } 15 \mathrm{~cm} \text { ASL. } \\
\text { The }\end{array}$ \\
\hline 18 & $10-11$ & 48 & 152 & 30 & 300 & Y & $\begin{array}{l}\text { conglomerate and } \\
\text { limestone }\end{array}$ & $\begin{array}{l}\text { The base of the MTN does not always occur. There are large blocks below the } \\
\text { sea level, and large balanids. }\end{array}$ \\
\hline 20 & - & 48 & 107 & 82 & 350 & $\mathrm{Y}$ & $\begin{array}{l}\text { conglomerate and } \\
\text { limestone }\end{array}$ & $\begin{array}{l}\text { Calcareous red algae inside the notch. There are several sea caves below the } \\
\text { base of the notch, and a large freshwater spring. }\end{array}$ \\
\hline 21 & $12-14$ & 44 & 143 & 78 & 250 & Y & $\begin{array}{l}\text { conglomerate and } \\
\text { limestone }\end{array}$ & Fossils of cervids and pulmonates. The MTN is partly collapsed. \\
\hline 22 & - & 44 & 135 & 74 & 350 & Y & $\begin{array}{l}\text { conglomerate and } \\
\text { limestone }\end{array}$ & $\begin{array}{l}\text { Red continental deposits seal Lithophaga holes containing pulmonata and } \\
\text { cervid bones. }\end{array}$ \\
\hline 23 & $\begin{array}{l}15-17, \\
19\end{array}$ & 43 & 140 & 54 & 20 & $\mathrm{~N}$ & limestone & Medium-large balanids replace corallinae algae. \\
\hline 24 & 18 & 45 & 109 & 58 & 40 & $\mathrm{~N}$ & limestone & \\
\hline 25 & $20-22$ & 41 & 220 & 65 & 100 & Y & limestone & $\begin{array}{l}\text { The sea level is } 10-12 \mathrm{~cm} \text { higher than the starting point, and the base of the } \\
\text { notch was roughly at sea level. A spectacular mushroom-like rock, } 6 \times 4 \mathrm{~m} \text { in } \\
\text { size and up to } 2 \mathrm{~m} \text { ASL in height. A slightly submerged platform lays all } \\
\text { around the aforementioned landform. Limpets were found inside the notch. }\end{array}$ \\
\hline $\begin{array}{l}\text { Mean } \\
\text { value }\end{array}$ & & 44,3 & 119.6 & 70.9 & 220.6 & & & \\
\hline
\end{tabular}


The biological trottoirs always consist of red coralline algae with a thickness between 5 and $12 \mathrm{~cm}$. At the beginning of the survey, at 09:15 a.m., 31 January 2020, all of the bases of the biological trottoirs were dry, while at the end of the survey, after about $3 \mathrm{~h}$ from the starting point, the tide had risen by almost $20 \mathrm{~cm}$, so perhaps for this reason some branches of Ellisolandia elongata were bleached (Figure 11: photos 16 and 19) due to light shock.

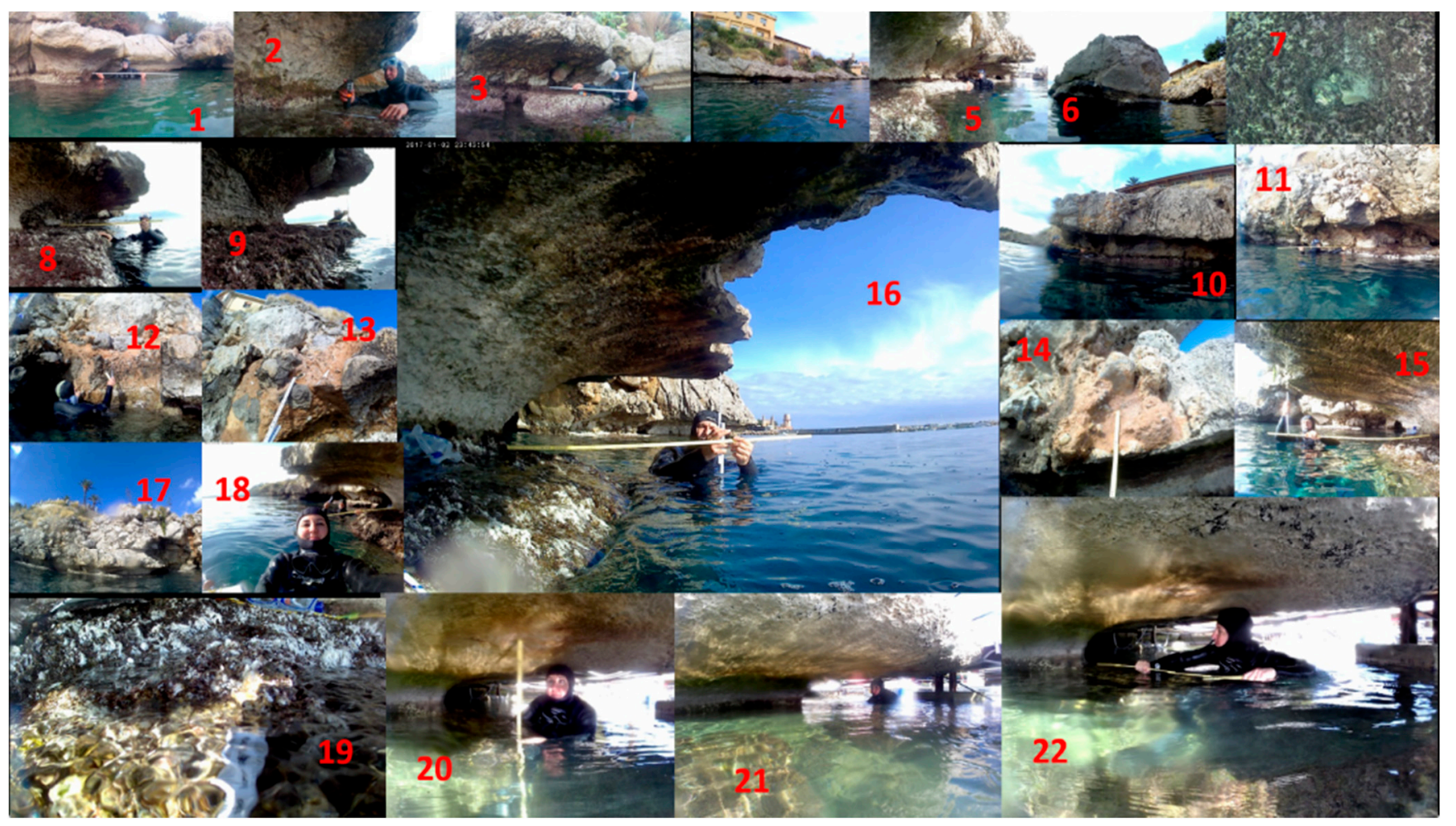

Figure 11. Collection of MTN images observed and measured in Palermo. The numbers in the pictures are related to the numbers in Table 3.

At tidal level, coralline algae always occur, but in some places were almost replaced by large balanids. From the base of the grooves to ca. $55 \mathrm{~cm}$ in height, Patella spp. occur. The notches are often very well preserved, with varying dimensions, as shown in Table 3 and Figures 10 and 11 . The width represents a rather small natural variability, with a maximum value of $50 \mathrm{~cm}$, minimum of $37 \mathrm{~cm}$, and an average of $44.3 \mathrm{~cm}-$ a value that compared with the local mean tide of $37.5 \mathrm{~cm}$ [14] appears quite normal (normally the width of the MTN has values between 8 and $20 \mathrm{~cm}$ wider than the mean local tide. Furthermore, the natural variability ( 25 measurements in $500 \mathrm{~m}$ ) is also certainly very low considering the measurement error $(2.5 \mathrm{~cm})$. As far as the depth of the furrow is concerned, it shows great variability, from 65 to $220 \mathrm{~cm}$. A remarkable aspect is visible in Figure 10, documenting a good correlation between the water spring and the depth of the MTN. This is a confirmation of how the presence of freshwater floating on top of marine water is able to deepen the MTN, near the outflow of submerged springs with a flow rate of 1000-3000 litres per second (such as at the resurgence of Cala Luna in the Gulf of Orosei, eastern Sardinia, where MTN depth exceeds $4.5 \mathrm{~m}$ ). The blue squares in Figure 10 indicate the spring waters that we have clearly recognized as coming out of small caves without any scientific equipment. Where the lithology changes from limestone to conglomerate, the base of the groove is oddly located $10-15 \mathrm{~cm}$ higher than that measured on limestone. Finally, between stations 15 and 17 we found small karst cavities completely filled with very well-cemented pinkish limestone together with a decimetric breccia containing fossil vertebrate fauna and pulmonate gastropods (Figure 11: photos 12-14). 


\subsection{Ansedonia Promontory}

The total length of the route around the promontory of Ansedonia was $3.9 \mathrm{~km}$ (Figure 12). The route was covered in 1 day, from the Taglio di Ansedonia, on its western part, to the so-called "Tagliata" channel in the eastern sector. Geologically, the promontory of Ansedonia is made of Mesozoic cavernous limestone, with a minor contribution of calcareous breccias. The promontory is mainly dominated by plunging cliffs, and a small sector of screes.
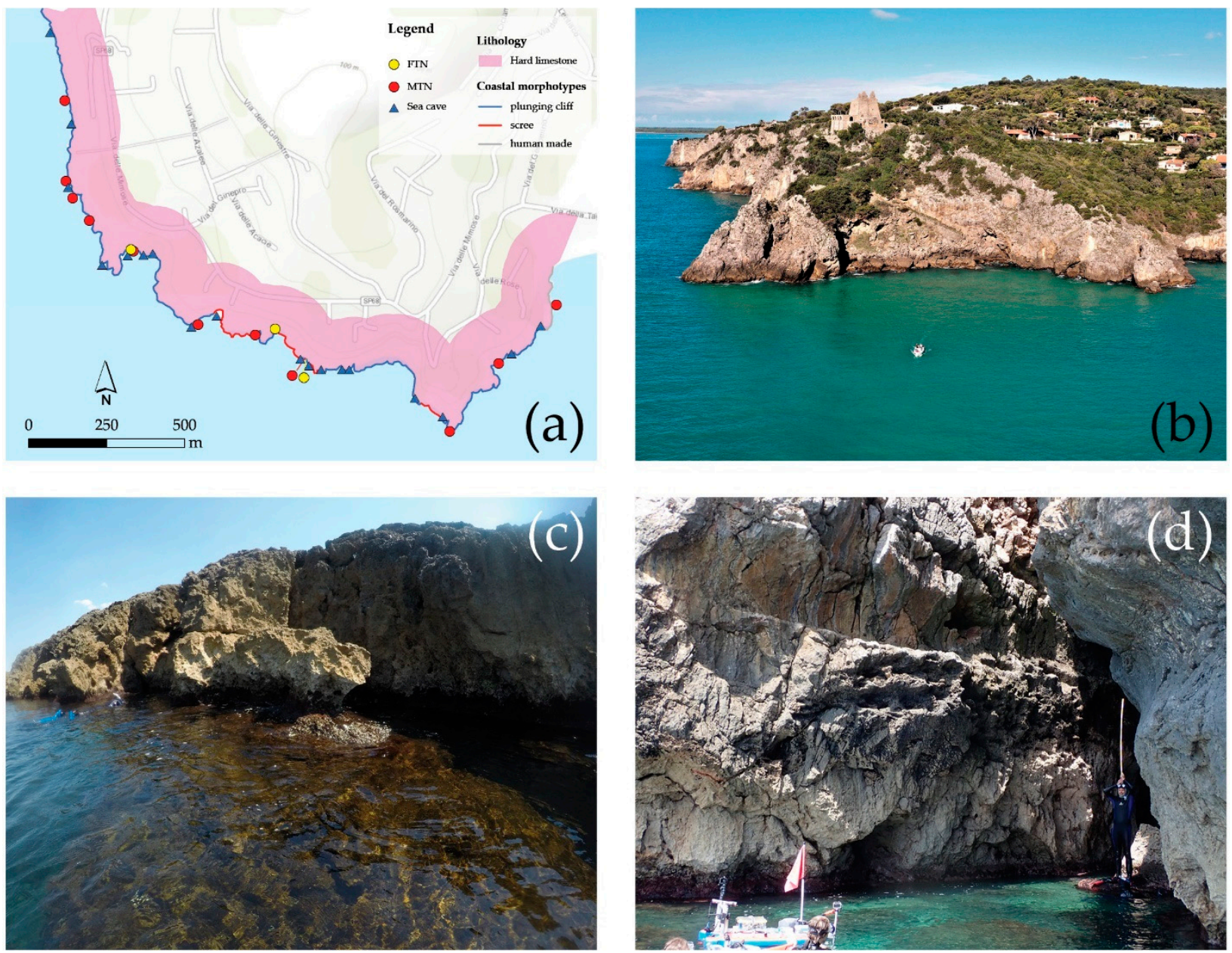

Figure 12. (a) Maps of the surveyed geomorphological features at the Ansedonia Promontory; (b) plunging cliffs in the southernmost sector of the promontory; (c) MTN at a mushroom rock; (d) FTN at about $4 \mathrm{~m}$ ASL.

Field surveys led to the mapping and measurement of 17 sites with MTNs. Their mean width was $0.56 \mathrm{~m}$ while their mean depth was $0.45 \mathrm{~m}$. is the sites were widely spread along the promontory. MTNs were found along $1368 \mathrm{~m}$ of coastline along plunging cliffs. There are two isolated mushroom-like limestone rocks with well-carved MTNs. An FTN was discovered for the first time at Ansedonia at an elevation of $4.5 \pm 0.50 \mathrm{~m}$ (Figure 12d), over a length of $10 \mathrm{~m}$. No MSPs were discovered, while a very small FMT-like landform was found at an altitude of about $3.0 \pm 0.50 \mathrm{~m} \mathrm{ASL}$, with well-carved potholes and other rounded landforms.

We surveyed 20 sea caves (Table 2); most of them are cut in limestone, with only one in carbonate breccia, and the inclusion of bauxite blocks on the eastern side of the promontory.

Among the characteristic species are Melarhaphe neritoides and Echinolittorina punctata in the supratidal zone; Patella rustica and Chthamalus stellatus inhabit substrates up to $1.5 \mathrm{~m}$ ASL, while Mytilus galloprovincialis appears localized next to freshwater springs. 


\section{Discussion}

The analysis of data collected during the swim surveys allowed us to describe the rocky coastlines in the study areas and discuss the relations between modern and fossil geomorphological sea level markers.

The swim surveys were carried out along $158.5 \mathrm{~km}$ of rocky coasts, mainly plunging cliffs and sloping coasts ( $78 \%$ of morphotypes). This is mainly due to an initial choice because, following [24], these morphotypes are more suitable for the acquisition of continuous perpendicular videos and time-lapse images, while the raft can be used more successfully as it can be simply pushed along predetermined routes at the same distance from the coast, rather than along scree coasts. Moreover, plunging cliffs and sloping coasts are good geomorphological environments for the formation of MTNs and FTNs. Several small pocket beaches were mapped, but generally not surveyed because they were not made of rocky outcrops. Some short sectors dominated by screes were also monitored along the routes, and in some cases the largest boulders at the sea level could host small sectors with MTNs, also in the shape of mushroom-like morphologies. Rocky coast shape depends mainly on the geological setting of the area $[28,29,60]$. Hard rocks allow the development of plunging cliffs or sloping coasts, while soft rocks, or soft layers of rocks, which are less resistant to the combined action of marine and subaerial processes, preferentially produce shore platforms or screes. MSPs were almost absent in our sites because very few useful data on sea level change can be collected from these types of coasts. In particular, $28 \%$ of the studied coasts are typified by plunging cliffs, $50 \%$ by sloping coasts, $10 \%$ by screes, $<1 \%$ by shore platforms, $5 \%$ by pocket beaches, and $6 \%$ are modified by human activity; these latter morphotypes were not included in the survey.

Our results show specific geomorphic associations related to the present and past sea levels, as described by many authors in tectonically stable areas $[55,88]$. The analysis carried out in the studied areas highlighted how a defined pattern of sea level markers can be established, mainly depending on the local lithology.

Data collected on erosional landforms show that MTNs occur over an average value of $36.4 \%$ of the total length of surveyed coasts. As is well known, tidal notches are present almost exclusively on carbonate coasts ([14] and references therein), apart from short sectors of extra-carbonatic coasts-such as volcanic coasts-that include short sectors of carbonate pockets [25]. Moreover, in this work, we have identified some short sectors of coasts in the granitic islands of Budelli with calcarenite layers with MTNs (Santa Maria Island, Section 5.3.1). The percentage of coverage of MTNs ranges from $0 \%$ on the carbonate promontory of Circeo up to $97.7 \%$ of the promontory of Gaeta. The first value is very anomalous because carbonate coasts in tectonic stable areas usually display tidal notches at sea level [14]. Even though we have no data, this could be due to local physical/chemical conditions of the sea water, or to the presence of Mytilus galloprovincialis, which could slow the erosion processes rather than the tectonic behaviour. On the Egadi Islands, MTNs could be potentially cut on large sectors of coast, but local lithology — dominated by dolostones-allows the development of small notches in relatively short sectors.

FTNs are quite rare, with values ranging from a few metres up to a maximum of $210 \mathrm{~m}$ in extent at Capo Caccia. Sometimes marine landforms occur at elevations lower than FTNs, showing that during MIS 5.5 the sea acted at elevations higher than today, but these landforms are only rarely coupled with fossil tidal notches. This is the case for Ansedonia, where we discovered an FTN at the promontory of Ansedonia at an elevation of $4.5 \pm 0.5 \mathrm{~m}$ ASL along a stretch of 10 metres. In some sea caves along the aforementioned promontory, there is clear evidence of the activity of paleo sea processes, with the occurrence of marine potholes, abraded smooth surfaces, and rounded blocks. These landforms are also common in the stretch between Mondello and Palermo. At the Circeo promontory, an FTN occurs within the Grotta delle Capre sea cave-as reported in [55]—which occurs above the present-day sea level. The geomorphological features associated with this notch are very well-preserved, probably because, as detailed in [55], it was covered by late Pleistocene and Holocene continental deposits that filled the cave (Figure 6d). Moreover, in this cave, 
Lithophaga lithophaga holes were found up to $0.3 \mathrm{~m}$ above the FTN, probably due to local mechanisms of wave pressure within the cave. The same mechanism took place in the sea caves at the Gaeta promontory. On Egadi Islands and in the carbonatic part of Sardinia, FTNs are relatively abundant, because of the occurrence of dolostones and hard carbonates, respectively. The percentage of coverage of FTNs with respect to the total length of the coast ranges from $0 \%$ to $1.4 \%$ at Capo Caccia (Table 2). Considering that such tidal notches should have been formed in lithological, weather, and sea conditions comparable to today's, this means that an average of $99.5 \%$ of fossil notches have been worn away by erosion, lowering rates of carbonates in the Mediterranean area outside the sea level range between $0.01 \mathrm{~mm} / \mathrm{yr}$ and $0.1 \mathrm{~mm} / \mathrm{yr}$ [89,90]. In other words, the total denudation rate in $125 \mathrm{kyrs}$ is able to erase $99.5 \%$ of landforms, leaving no trace, or almost no trace, of past environments. Fortunately, studies of past sea levels can make use of sedimentological data found in nearby areas, and may allow assessment of the behaviour of larger areas (e.g., [55], making up for the lack of purely geomorphological data). In other cases, the stability of an area is also assessed based on geomorphological data, so one must be lucky enough to identify sites that have been preserved. The most difficult aspect of evaluating the maximum information from a displaced geomorphic feature is the absence of a well-documented age for the landforms [52], but this is surpassed in the aforementioned case by a certain age of FTNs and FMTs.

Regarding MSPs, we found them only along short sectors of the Maltese coast, which has already been reported in [28] and discussed in [91,92]. MSPs are near-horizontal, with a gradient of about $1^{\circ}$ or less, following the features described in [60] for microtidal environments. However, the studied MSPs are above the maximum tide level, at about $1 \mathrm{~m}$ ASL, so they are supratidal landforms. They can be formed partly due to selective erosion rather than cliff retreat. The maximum measured width in the study area for MSPs was some tens of metres. All of the surveyed MSPs had a scarp at the seaward edge. The size and width of such surveyed landforms depend on the rock resistance of the shore platform [60], dipping of strata [56], retreat rates of landward cliffs, and [93] the time when they were initiated at the beginning of the Holocene stillstand (about 7 kyrs BP). On the other hand, FMTs were not reported, probably because the soft nature of local limestones prevents their preservation. Other authors also never reported the presence of these terraces [91,94-97]. For the opposite reason, MSPs and FMTs were not discovered in the other studied sites. Carbonate rocks in the studied sites are very resistant to erosion processes, and it is likely that during the MIS 5.5 transgression there was not enough time to carve out shore platforms. Only at Favignana Island does an FMT occur at about $5 \mathrm{~m}$ [95], while in the stretch of coast between Mondello and Palermo and at the Ansedonia promontory, marine-like features—such as potholes, rounded blocks, and smoothed features-occur above the modern sea level.

Vermetid reefs are well-developed in the eastern and southern parts of the studied area, in particular at Capo Caccia and the Egadi Islands. Their width ranges in size between few centimetres to several metres on low-lying rocky coasts. The morphometry of Vermetid reefs indicates that these are fairly extensive forms-more on shallow sectors, less on sloping shorelines, with no "steps" related to co-seismic events (terraces on trottoirs, etc.), consistent with stable island tectonics.

\section{Conclusions}

All of the studied areas are considered to be tectonically stable. The results of swim surveys in the central Mediterranean Sea showed that the network of coastal erosional landforms of tectonically stable areas can partially be found in the typical assemblages, which mainly depend on the lithology and the shape of the coast, or coastal morphotypes. The extent, shape, and morphometric features reflect lithology and local sea level history, considering the eustatic contribution to the sea level, the tectonics, and the GIA component.

MTNs occur along wide sectors of carbonate coasts - up to $97.7 \%$ of the local coastline, mainly on plunging cliffs and sloping coasts. The measurement of the lateral extent of 
these landforms indicates that MTNs are present in all of the study areas except for the Circeo Promontory. Here, MTNs do not occur, possibly because of local physical/chemical conditions of the sea water. On the other hand, FTNs are very rare, covering a maximum of a few hundred metres at Capo Caccia (Sardinia). FTNs also occur at Marettimo and Levanzo islands, Gaeta, Ansedonia Promontory, Capo Caccia, and Tavolara, at elevations ranging from 4.5 to $9 \mathrm{~m}$ ASL. Furthermore, at the Circeo Promontory, an FTN is well carved inside a sea cave. In general, FTNs are preserved only where they could have been previously covered by continental deposits that were almost totally removed by the Holocene transgression. In the other cases, weathering and erosion processes that occurred between MIS 5.5 and today removed such landforms. These results also support the theory that current bedrock lowering values measured on limestones-in the Mediterranean and outside it, however few microns per year [58]—can consume a notch-sized landform within a hundred thousand years.

The ratio between modern and fossil tidal notches provides the amount of denudation over the last $125 \mathrm{kyrs}$. We calculated that the average denudation rate of erosional landforms was $99.5 \%$ over this timeframe. This means that only very small features have a chance to last, so a lot of luck is needed for them to be preserved, and also for scientific research to eventually discover them.

Author Contributions: Conceptualization, S.F. and F.A.; methodology, S.F. and F.A.; software, S.B. and C.B.; validation, F.A.; formal analysis, S.B.; investigation, S.F., V.V., F.A., M.A., S.B., C.B., A.B., F.C. (Francesco Caldareri), F.C. (Fabio Canziani), R.C., G.D., J.C.D., E.D.B., S.D., E.D.S., Y.D., R.G., T.G., V.L.P., P.M., A.N., P.E.O., A.P., J.A.S., M.T., F.T., E.T., M.V., E.V.; data curation, S.B. and V.V.; writing-original draft preparation, S.F., F.A., S.B., M.A., F.C. (Francesco Caldareri), R.C., R.G. and T.G.; writing-review and editing, S.F., F.A., S.B., J.C.D., R.C., R.G., J.A.S., M.T. and M.V.; visualization, S.B., C.B. and M.A.; supervision, S.F.; project administration, S.F., E.D.S., Y.D. and A.N.; funding acquisition, S.F., E.D.S., Y.D. and A.N.; all of the authors partly funded the expeditions. All authors have read and agreed to the published version of the manuscript.

Funding: This research received no external funding.

Acknowledgments: We are very grateful to the MPA Isole Egadi for funding part of the fieldwork trip of Geoswim 3.0; to the National Park of the Maddalena Archipelago, MPA Tavolara, and MPA Capo Caccia-Isola Piana for funding part of the fieldwork trip of Geoswim 2015 Sardinia; and to the Department of Geography of the University of Malta for funding part of the fieldwork trip of Geoswim Malta 2015. We thank the University of Trieste and Cagliari for the use of the Punta Sardegna lighthouse. Moreover, we also thank Marianna Bellotto, Federica Muro, and Enrico Zavagno for field surveys, as well as the support staff of all the campaigns.

Conflicts of Interest: The authors declare no conflict of interest.

\author{
Abbreviations \\ LGM Last glacial maximum \\ MTN Modern tidal notch \\ FTN Fossil tidal notch \\ MSP Modern shore platform \\ FMT Fossil marine terrace \\ ASL Above sea level \\ BSL Below sea level \\ LCL Lower Coralline Limestone \\ LGL Lower Globigerina Limestone \\ MGL Middle Globigerina Limestone \\ UGL Upper Globigerina Limestone \\ MIS Marine isotope stage
}




\section{References and Note}

1. Anzidei, M.; Lambeck, K.; Antonioli, F.; Furlani, S.; Mastronuzzi, G.; Serpelloni, E.; Vannucci, G. Coastal Structure, Sea-Level Changes and Vertical Motion of the Land in the Mediterranean. Geol. Soc. Lond. 2014, 388, 453-479. [CrossRef]

2. Furlani, S.; Ninfo, A.; Zavagno, E.; Paganini, P.; Zini, L.; Biolchi, S.; Antonioli, F.; Coren, F.; Cucchi, F. Submerged notches in Istria and the Gulf of Trieste: Results from the Geoswim Project. Quat. Int. 2014, 332, 37-47. [CrossRef]

3. Rovere, A.; Raymo, M.E.; Vacchi, M.; Lorscheid, T.; Stocchi, P.; Gómez-Pujol, L.; Harris, D.L.; Casella, E.; O’Leary, M.J.; Hearty, P.J. The Analysis of Last Interglacial (MIS 5e) Relative Sea-Level Indicators: Reconstructing Sea-Level in a Warmer World. Earth-Sci. Rev. 2016, 159, 404-427. [CrossRef]

4. Shennan, I.; Long, A.J.; Horton, B.P. Handbook of Sea-Level Research; John Wiley \& Sons: Hoboken, NJ, USA, 2015.

5. Benjamin, J.; Rovere, A.; Fontana, A.; Furlani, S.; Vacchi, M.; Inglis, R.H.; Galili, E.; Antonioli, F.; Sivan, D.; Miko, S.; et al. Late Quaternary Sea-Level Changes and Early Human Societies in the Central and Eastern Mediterranean Basin: An Interdisciplinary Review. Quat. Int. 2017, 449, 29-57. [CrossRef]

6. Peltier, W.R. On Eustatic Sea Level History: Last Glacial Maximum to Holocene. Quat. Sci. Rev. 2002, 21, 377-396. [CrossRef]

7. Mitrovica, J.X.; Milne, G.A. On the Origin of Late Holocene Sea-Level Highstands within Equatorial Ocean Basins. Quat. Sci. Rev. 2002, 21, 2179-2190. [CrossRef]

8. Bradley, S.L.; Milne, G.A.; Horton, B.P.; Zong, Y. Modelling Sea Level Data from China and Malay-Thailand to Estimate Holocene Ice-Volume Equivalent Sea Level Change. Quat. Sci. Rev. 2016, 137, 54-68. [CrossRef]

9. Pirazzoli, P.A.; Laborel, J.; Stiros, S.C. Earthquake Clustering in the Eastern Mediterranean during Historical Times. J. Geophys. Res. Solid Earth 1996, 101, 6083-6097. [CrossRef]

10. Pirazzoli, P.A. A Review of Possible Eustatic, Isostatic and Tectonic Contributions in Eight Late-Holocene Relative Sea-Level Histories from the Mediterranean Area. Quat. Sci. Rev. 2005, 24, 1989-2001. [CrossRef]

11. Lambeck, K.; Antonioli, F.; Purcell, A.; Silenzi, S. Sea-Level Change along the Italian Coast for the Past 10,000 yr. Quat. Sci. Rev. 2004, 23, 1567-1598. [CrossRef]

12. Lambeck, K.; Antonioli, F.; Anzidei, M.; Ferranti, L.; Leoni, G.; Scicchitano, G.; Silenzi, S. Sea Level Change along the Italian Coast during the Holocene and Projections for the Future. Quat. Int. 2011, 232, 250-257. [CrossRef]

13. Antonioli, F.; Anzidei, M.; Lambeck, K.; Auriemma, R.; Gaddi, D.; Furlani, S.; Orrù, P.; Solinas, E.; Gaspari, A.; Karinja, S.; et al. Sea-Level Change during the Holocene in Sardinia and in the Northeastern Adriatic (Central Mediterranean Sea) from Archaeological and Geomorphological Data. Quat. Sci. Rev. 2007, 26, 2463-2486. [CrossRef]

14. Antonioli, F.; Lo Presti, V.; Rovere, A.; Ferranti, L.; Anzidei, M.; Furlani, S.; Mastronuzzi, G.; Orru, P.E.; Scicchitano, G.; Sannino, G.; et al. Tidal Notches in Mediterranean Sea: A Comprehensive Analysis. Quat. Sci. Rev. 2015, 119, 66-84. [CrossRef]

15. Antonioli, F.; Anzidei, M.; Amorosi, A.; Lo Presti, V.; Mastronuzzi, G.; Deiana, G.; De Falco, G.; Fontana, A.; Fontolan, G.; Lisco, S.; et al. Sea-Level Rise and Potential Drowning of the Italian Coastal Plains: Flooding Risk Scenarios for 2100. Quat. Sci. Rev. 2017, 158, 29-43. [CrossRef]

16. Padgett, J.S.; Kelsey, H.M.; Lamphear, D. Upper-Plate Deformation of Late Pleistocene Marine Terraces in the Trinidad, California, Coastal Area, Southern Cascadia Subduction Zone. Geosphere 2019, 15, 1323-1341. [CrossRef]

17. Antonioli, F.; Ferranti, L.; Kershaw, S. A Glacial Isostatic Adjustment Origin for Double MIS 5.5 and Holocene Marine Notches in the Coastline of Italy. Quat. Int 2006, 145-146, 19-29. [CrossRef]

18. Chemello, R.; Silenzi, S. Vermetid Reefs in the Mediterranean Sea as Archives of Sea-Level and Surface Temperature Changes. Chem. Ecol. 2011, 27, 121-127. [CrossRef]

19. Sisma-Ventura, G.; Antonioli, F.; Silenzi, S.; Devoti, S.; Montagna, P.; Chemello, R.; Shemesh, A.; Yam, R.; Gehrels, R.; Dean, S.; et al. Assessing Vermetid Reefs as Indicators of Past Sea Levels in the Mediterranean. Mar. Geol. 2020, 429, 106-313. [CrossRef]

20. Mauz, B.; Vacchi, M.; Green, A.; Hoffmann, G.; Cooper, A. Beachrock: A Tool for Reconstructing Relative Sea Level in the Far-Field. Mar. Geol. 2015, 362, 1-16. [CrossRef]

21. Mourtzas, N.; Kolaiti, E. Shoreline Reconstruction of the Submerged Minoan Harbour Morphology in the Bay of Kato Zakros (Eastern Crete, Greece). J. Archaeol. Sci. Rep. 2017, 12, 684-698. [CrossRef]

22. Antonioli, F.; De Falco, G.; Lo Presti, V.; Moretti, L.; Scardino, G.; Anzidei, M.; Bonaldo, D.; Carniel, S.; Leoni, G.; Furlani, S.; et al. Relative Sea-Level Rise and Potential Submersion Risk for 2100 on 16 Coastal Plains of the Mediterranean Sea. Water 2020, 12, 2173. [CrossRef]

23. Auriemma, R.; Solinas, E. Archaeological Remains as Sea Level Change Markers: A Review. Quat. Int. 2009, 206, 134-146. [CrossRef]

24. Furlani, S. Integrating Observational Targets and Instrumental Data on Rock Coasts through Snorkel Surveys: A Methodological Approach. Mar. Geol. 2020, 425, 106-191. [CrossRef]

25. Furlani, S. The Rocky Coasts of the Mediterranean Sea: Field Studies. In Proceedings of the Coastal and Maritime Mediterranean Conference, Split, Croatia, 29 November-1 December 2017; pp. 39-44.

26. Furlani, S.; Antonioli, F.; Gambin, T.; Gauci, R.; Ninfo, A.; Zavagno, E.; Micallef, A.; Cucchi, F. Marine Notches in the Maltese Islands (Central Mediterranean Sea). Quat. Int. 2017, 439, 158-168. [CrossRef]

27. Furlani, S.; Pappalardo, M.; Gómez-Pujol, L.; Chelli, A. The rock coast of the Mediterranean and Black Seas. In Geological Society; London, Memoirs: London, UK, 2014; Volume 40, pp. 89-122. 
28. Biolchi, S.; Furlani, S.; Devoto, S.; Gauci, R.; Castaldini, D.; Soldati, M. Geomorphological Identification, Classification and Spatial Distribution of Coastal Landforms of Malta (Mediterranean Sea). J. Maps 2016, 12, 87-99. [CrossRef]

29. Biolchi, S.; Furlani, S.; Antonioli, F.; Baldassini, N.; Causon Deguara, J.; Devoto, S.; Di Stefano, A.; Evans, J.; Gambin, T.; Gauci, R.; et al. Boulder Accumulations Related to Extreme Wave Events on the Eastern Coast of Malta. Nat. Hazards Earth Syst. Sci. 2016, 16, 737-756. [CrossRef]

30. Mather, A. The Physical Geography of the Mediterranean; OUP Oxford: Oxford, UK, 2009; ISBN 978-0-19-160841-4.

31. International Hydrographic Organization (IHO); Sieger, R. Names of Oceans and Seas as Digitized Table. Alfred Wegener Institute, Helmholtz Centre for Polar and Marine Research, Bremerhaven, PANGAEA. 2012. Available online: https:/ / doi.org/10 .1594/PANGAEA.777976 (accessed on 25 July 2021).

32. Mastronuzzi, G.; Antonioli, F.; Anzidei, M.; Auriemma, R.; Alfonso, C.; Scarano, T. Evidence of Relative Sea Level Rise along the Coasts of Central Apulia (Italy) during the Late Holocene via Maritime Archaeological Indicators. Quat. Int. 2017, 439, 65-78. [CrossRef]

33. Selli, R. Appunti Sulla Geologia Del Mar Tirreno. Rendiconti Semin. Fac Sci Univ Cagliari 1974, 327-349.

34. Malinverno, A.; Ryan, W.B.F. Extension in the Tyrrhenian Sea and Shortening in the Apennines as Result of Arc Migration Driven by Sinking of the Lithosphere. Tectonics 1986, 5, 227-245. [CrossRef]

35. Kastens, K.; Mascle, J.; Auroux, C.; Bonatti, E.; Broglia, C.; Channell, J.; Curzi, P.; Emeis, K.-C.; Glaçon, G.; Hasegawa, S.; et al. ODP Leg 107 in the Tyrrhenian Sea: Insights into Passive Margin and Back-Arc Basin Evolution. GSA Bull. 1988, 100, 1140-1156. [CrossRef]

36. Selli, R. Cenni Morfologici Generali Sul Mar Tirreno. G Geol. 1970, 37, 5-24.

37. Chiocci, F.L.; D’Angelo, S.; Romagnoli, C. Atlante Dei Terrazzi Deposizionali Sommersi Lungo Le Coste Italiane. Mem. Descr. Della Carta Geol. D'Italia 2004, 58, 197.

38. Catalano, S.; Torrisi, S.; Tortorici, G.; Romagnoli, G. Active Folding along a Rift-Flank: The Catania Region Case History (SE Sicily). J. Geodyn. 2011, 51, 53-63. [CrossRef]

39. Gasparo Morticelli, M.; Valenti, V.; Catalano, R.; Sulli, A.; Agate, M.; Avellone, G.; Albanese, C.; Basilone, L.; Gugliotta, C. Deep Controls on Foreland Basin System Evolution along the Sicilian Fold and Thrust Belt. Bull. Soc. Geol. Fr. 2015, 186, 273-290. [CrossRef]

40. GEBCO. The General Bathymetric Chart of the Oceans. Available online: https:/ / www.gebco.net/ (accessed on 9 June 2021).

41. Bigi, G.; Cosentino, D.; Parotto, M.; Sartori, R.; Scandone, P. Structural Model of Italy 1:500,000. CNR Progetto Final. Geodin. 1992, 3, 114.

42. Sulli, A.; Morticelli, M.G.; Agate, M.; Zizzo, E. Active North-Vergent Thrusting in the Northern Sicily Continental Margin in the Frame of the Quaternary Evolution of the Sicilian Collisional System. Tectonophysics 2021, 802, 228717. [CrossRef]

43. Max, M.D.; Kristensen, A.; Michelozzi, E. Small Scale Plio-Quaternary Sequence Stratigraphy and Shallow Geology of the West-Central Malta Plateau. Geol. Dev. Sicil. Tunis. Platf. 1993, 58, 117-122.

44. Micallef, A.; Camerlenghi, A.; Georgiopoulou, A.; Garcia-Castellanos, D.; Gutscher, M.-A.; Lo Iacono, C.; Huvenne, V.A.I.; Mountjoy, J.J.; Paull, C.K.; Le Bas, T.; et al. Geomorphic Evolution of the Malta Escarpment and Implications for the Messinian Evaporative Drawdown in the Eastern Mediterranean Sea. Geomorphology 2019, 327, 264-283. [CrossRef]

45. Gauci, R.; Scerri, S. A Synthesis of Different Geomorphological Landscapes on the Maltese Islands. In Landscapes and Landforms of the Maltese Islands; Gauci, R., Schembri, J.A., Eds.; World Geomorphological Landscapes Springer: Cham, Switzerland, 2019; pp. $49-65$.

46. Alexander, D. A Review of the Physical Geography of Malta and Its Significance for Tectonic Geomorphology. Quat. Sci. Rev. 1988, 7, 41-53. [CrossRef]

47. Pedley, M. The Calabrian Stage, Pleistocene Highstand in Malta: A New Marker for Unravelling the Late Neogene and Quaternary History of the Islands. J. Geol. Soc. 2011, 168, 913-926. [CrossRef]

48. Rohling, E.J.; Abu-Zied, R.; Casford, C.S.L.; Hayes, A.; Hoogakker, B.A.A. The Mediterranean Sea: Present and Past. In Physical Geography of the Mediterranean Basin; Oxford Regional Environments; Oxford University Press: Oxford, UK, 2009; ISBN 978-0-19-926803-0.

49. McElderry, J.H. Mediterranean Tides and Currents. Ir. Astron. J. 1963, 6, 12.

50. Pinet, P.R. Invitation to Oceanography; West Publishing Co: St. Paul, MN, USA, 1996.

51. Izquierdo, A.; Mikolajewicz, U. The Role of Tides in the Spreading of Mediterranean Outflow Waters along the Southwestern Iberian Margin. Ocean Model. 2019, 133, 27-43. [CrossRef]

52. Burbank, D.W.; Anderson, R.S. Tectonic Geomorphology; John Wiley \& Sons: Hoboken, NJ, USA, 2009; ISBN 978-1-4443-1311-6.

53. Sunamura, T. The Elevation of Shore Platforms: A Laboratory Approach to the Unsolved Problem. J. Geol. 1991, 99, 761-766. [CrossRef]

54. Trenhaile, A.S. Coastal Notches: Their Morphology, Formation, and Function. Earth Sci. Rev. 2015, 150, 285-304. [CrossRef]

55. Antonioli, F.; Ferranti, L.; Stocchi, P.; Deiana, G.; Lo Presti, V.; Furlani, S.; Marino, C.; Orru, P.; Scicchitano, G.; Trainito, E.; et al. Morphometry and Elevation of the Last Interglacial Tidal Notches in Tectonically Stable Coasts of the Mediterranean Sea. Earth Sci. Rev. 2018, 185, 600-623.

56. Trenhaile, A.S. The Geomorphology of Rock Coasts; Clarendon Press: Budapest, Hungary, 1987. 
57. Antonioli, F.; Furlani, S.; Montagna, P.; Stocchi, P. The Use of Submerged Speleothems for Sea Level Studies in the Mediterranean Sea: A New Perspective Using Glacial Isostatic Adjustment (GIA). Geosciences 2021, 11, 77. [CrossRef]

58. Furlani, S.; Cucchi, F.; Biolchi, S. Late Holocene widening of karst voids by marine processes in partially submerged coastal caves (northeastern Adriatic sea). Geogr. Fis. E Din. Quat. 2012, 35, 129-140.

59. De Waele, J.; Furlani, S. Seawater and Biokarst Effects on Coastal Limestones. In Treatise on Geomorphology; Shroder, J.F., Ed.; Academic Press: San Diego, CA, USA, 2013; Volume 6, pp. 341-350.

60. Sunamura, T. Geomorphology of Rocky Coasts; John Wiley \& Sons: Chichester, UK, 1992; ISBN 0471917753.

61. Mylroie, J.E.; Carew, J.L. The Flank Margin Model for Dissolution Cave Development in Carbonate Platforms. Earth Surf. Process. Landf. 1990, 15, 413-424. [CrossRef]

62. Antonioli, F.; Chemello, R.; Improta, S.; Riggio, S. Dendropoma Lower Intertidal Reef Formations and Their Palaeoclimatological Significance, NW Sicily. Mar. Geol. 1999, 161, 155-170. [CrossRef]

63. Chemello, R. La Bionomia Bentonica Ed i Molluschi. Il Piano Infralitorale: Il Marciapiede a Vermeti. Not. SIM 1989, 7, 167-170.

64. Chemello, R.; Pandolfo, A.; Riggio, S. Le Biocostruzioni a Molluschi Vermetidi Nella Sicilia Nord-Occidentale. In Proceedings of the Atti 53 Congresso UZI 1990, Palermo, Italy, 1-5 October 1990.

65. Chemello, R. Le Biocostruzioni Marine in Mediterraneo. Lo Stato Delle Conoscenze Sui Reef a Vermeti. Biol. Mar. Mediterr. 2009, 16, 2-18.

66. Consoli, P.; Romeo, T.; Giongrandi, U.; Andaloro, F. Differences among Fish Assemblages Associated with a Nearshore Vermetid Reef and Two Other Rocky Habitats along the Shores of Cape Milazzo (Northern Sicily, Central Mediterranean Sea). Mar. Biol. Assoc. U. K. J. 2008, 88, 401-410. [CrossRef]

67. Milazzo, M.; Fine, M.; La Marca, E.C.; Alessi, C.; Chemello, R. Drawing the Line at Neglected Marine Ecosystems: Ecology of Vermetid Reefs in a Changing Ocean. Mar. Anim. For. 2016, 120, 1-23.

68. Sea Level Station Monitoring Facility. Available online: http://www.ioc-sealevelmonitoring.org/map.php (accessed on 17 June 2021).

69. Egbert, G.D.; Erofeeva, S.Y. Efficient Inverse Modeling of Barotropic Ocean Tides. J. Atmospheric Ocean. Technol. 2002, 19, 183-204. [CrossRef]

70. Carobene, L. Osservazioni sui solchi di battente attuali ed antichi nel golfo di Oresei in Sardegna. Mem. Soc. Geol. It. 1972, 19, 641-649.

71. Carobene, L. Pasini Contributo Alla Conscenza Del Pleistocene Superiore e Dell'Olocene Del Golfo Di Orosei (Sadegna Orientale). Boll. Della Soc. Adriat. Sci. 1980, 114, 5-36.

72. Furlani, S.; Cucchi, F.; Biolchi, S.; Odorico, R. Notches in the Northern Adriatic Sea: Genesis and Development. Quat. Int. 2011, 232, 158-168. [CrossRef]

73. Abate, B.; Incandela, A.; Renda, P. Carta Geologica delle Isole di Favignana e Levanzo. Diploma Thesis, Di Geologia e Geodesia dell’Università degli Studi di Palermo, Palermo, Italy, 1997.

74. Cardello, G.L. Rilevamento Geologico del Promontorio del Circeo: Analisi di Facies ed Evoluzione Tettono-Stratigrafica. Master's Thesis, University of Rome "La Sapienza", Rome, Italy, 2006.

75. Rossi, D.; Bigi, S.; Del Castello, M.; Di Manna, P. The Structure of the Aurunci Mountains (Southern Lazio): A Balanced Cross-Section and Its Restoration. Boll. Della Soc. Geol. Ital. Vol. Spec. 2002, 1, 151-159.

76. Regione Toscana. Available online: https://www.regione.toscana.it/ (accessed on 17 June 2021).

77. Miragoli, M. Le Grotte Delle Egadi, Contributo Aggiuntivo.; Catania, Sicily, 11th December 1994; Vol. Boll Acc. Gioenia di Sc. Nat. 1994, pp. 413-429. Available online: https:/ / www.biodiversitylibrary.org/bibliography/6339 (accessed on 25 July 2021).

78. Antonioli, F.; Lo Presti, V.; Morticelli, M.G.; Bonfiglio, L.; Mannino, M.A.; Palombo, M.R.; Sannino, G.; Ferranti, L.; Furlani, S.; Lambeck, K.; et al. Timing of the Emergence of the Europe-Sicily Bridge (40-17 Cal Ka BP) and Its Implications for the Spread of Modern Humans. Geol. Soc. Lond. Spec. Publ. 2016, 411, 111-144. [CrossRef]

79. Laborel, J.; Morhange, C.; Lafont, R.; Le Campion, J.; Laborel-Deguen, F.; Sartoretto, S. Biological Evidence of Sea-Level Rise during the Last 4500 Years on the Rocky Coasts of Continental Southwestern France and Corsica. Mar. Geol. 1994, 120, 203-223. [CrossRef]

80. Laborel, J.; Laborel-Deguen, F. Biological Indicators of Relative Sea-Level Variations and of Co-Seismic Displacements in the Mediterranean Region. J. Coast. Res. 1994, 10, 395-415.

81. Segre, A.G. Nota Sui Rilevamenti Eseguiti Nel Foglio 158 Latina Della Carta Geologica d'Italia; Tip. del Senato del dott. G. Bardi, 1957.

82. Bietti, A.; Grimaldi, S. Small Flint Pebbles and Mousterian Reduction Chains: The Case of Southern Latium (Italy). Quaternaria Nova 1996, 6, 237-260.

83. Durante, S. Il Tirreniano e Malacofauna Della Grotta Fossellone (Circeo). 1974. Available online: http:/ / pascal-francis.inist.fr / vibad/index.php?action=getRecordDetail\&idt=PASCALGEODEBRGM7720220288 (accessed on 25 July 2021).

84. Mottershead, D.; Bray, M.; Causon Deguara, J. Tsunamigenic Landscapes in the Maltese Islands: The Comino Channel Coasts. In Landscapes and Landforms of the Maltese Islands; Gauci, R., Schembri, J.A., Eds.; World Geomorphological Landscapes; Springer International Publishing: Cham, Switzerland, 2019; pp. 273-288.

85. Galve, J.P.; Tonelli, C.; Gutiérrez, F.; Lugli, S.; Vescogni, A.; Soldati, M. New Insights into the Genesis of the Miocene Collapse Structures of the Island of Gozo (Malta, Central Mediterranean Sea). J. Geol. Soc. 2015, 172, 336-348. [CrossRef]

86. Azzopardi, L.; Schembri, P. Vermetid Crusts from the Maltese Islands (Central Mediterranean). Mar. Life 1997, 7, 7-16. 
87. Soldati, M.; Tonelli, C.; Galve, J.P. Geomorphological Evolution of Palaeo-sinkhole Features in the Maltese Archipelago (Mediterranean Sea). Geogr. Fis. E Din. Quat. 2013, 36, 189-198.

88. Ferranti, L.; Antonioli, F.; Mauz, B.; Amorosi, A.; Dai Pra, G.; Mastronuzzi, G.; Monaco, C.; Orrù, P.; Pappalardo, M.; Radtke, U.; et al. Markers of the Last Interglacial Sea-Level High Stand along the Coast of Italy: Tectonic Implications. Quat. Int. 2006, 145-146, 30-54. [CrossRef]

89. Furlani, S.; Cucchi, F.; Forti, F.; Rossi, A. Comparison between Coastal and Inland Karst Limestone Lowering Rates in the Northeastern Adriatic Region (Italy and Croatia). Geomorphology 2009, 104, 73-81. [CrossRef]

90. Furlani, S.; Cucchi, F. Downwearing Rates of Vertical Limestone Surfaces in the Intertidal Zone (Gulf of Trieste, Italy). Mar. Geol. 2013, 343, 92-98. [CrossRef]

91. Gauci, R. The Identification and Quantification of Surface Change on Limestone Shore Platforms of the Maltese Islands. Ph.D Thesis, University of Portsmouth, Portsmouth, UK, 2018.

92. Gauci, R.; Inkpen, R. The Physical Characteristics of Limestone Shore Platforms on the Maltese Islands and Their Neglected Contribution to Coastal Land Use Development. In Landscapes and Landforms of the Maltese Islands; Gauci, R., Schembri, J.A., Eds.; World Geomorphological Landscapes; Springer International Publishing: Cham, Switzerland, 2019; pp. 343-356.

93. Stephenson, W.J.; Dickson, M.E.; Trenhaile, A.S. Rock Coasts. In Treatise on Geomorphology; Shroder, J.F., Ed.; Academic Press: San Diego, CA, USA, 2013; Volume 10, pp. 289-307.

94. Paskoff, R.; Sanlaville, P. Geomorphologic Observations on Maltese Archipelago Coasts. Z Geomorph 1978, $310-328$.

95. Furlani, S.; Antonioli, F.; Biolchi, S.; Gambin, T.; Gauci, R.; Lo Presti, V.; Anzidei, M.; Devoto, S.; Palombo, M.R.; Sulli, A. Reply to Comment by C. Morhange, C. Flaux, P.A. Pirazzoli, M.B. Carre on "Holocene Sea Level Change in Malta". Quat. Int. 2013, 303, 235-236. [CrossRef]

96. Gauci, R.; Schembri, J.A. Landscapes and Landforms of the Maltese Islands; World Geomorphological Landscapes; Springer: Cham, Switzerland, 2019.

97. Presti, V.L.; Antonioli, F.; Palombo, M.R.; Agnesi, V.; Biolchi, S.; Calcagnile, L.; Di Patti, C.; Donati, S.; Furlani, S.; Merizzi, J.; et al. Palaeogeographical Evolution of the Egadi Islands (Western Sicily, Italy). Implications for Late Pleistocene and Early Holocene Sea Crossings by Humans and Other Mammals in the Western Mediterranean. Earth Sci. Rev. 2019, 194, 160-181. [CrossRef] 